\title{
A Taxonomy of Financial Crisis Resolution Mechanisms: Cross-Country Experience
}

\author{
Charles W. Calomiris, Daniela Klingebiel, and Luc Laeven*
}

\begin{abstract}
The goals of financial restructuring are to re-establish the creditor-debtor relationships upon which the economy depends for an efficient allocation of capital, and to accomplish that objective at minimal cost. Costs include direct costs to taxpayers of financial assistance and the indirect costs to the economy that result from misallocations of capital and incentive problems resulting from the restructuring. We review cases in which countries employed alternative mechanisms to restructure their financial and corporate sectors. Countries typically apply a combination of tools, including decentralized, market-based mechanisms and government-managed programs. Market-based strategies seek to strengthen the capital base of financial institutions and/or borrowers to enable them to renegotiate debt and resume new credit supply. Government-led restructuring strategies often include the establishment of an entity to which non-performing loans are transferred or the government's sale of financial institutions, sometimes to foreign entrants. Market-based mechanisms can, in principle, resolve coordination problems countries face in the wake of massive debtor and creditor insolvency, with acceptably low direct and indirect costs, particularly when those mechanisms are effective in achieving the desirable objective of selectivity. However, these mechanisms depend for their success on an efficient judicial system, a credible supervisory framework and authority with sufficient enforcement capacity, and a lack of corruption in implementation. Government-managed programs may not seem to depend as much on efficient legal and supervisory institutions for their success, but in fact these approaches, in particular the transfer of assets to government-owned asset management companies, also depend on effective legal, regulatory, and political institutions for their success. Further, a lack of attention to incentive problems when designing specific rules governing financial assistance can aggravate moral hazard problems, unnecessarily raising the costs of resolution. These results suggest that policymakers in emerging market economies with weak institutions should not expect to achieve the same level of success in financial restructuring as other countries, and that they should design resolution mechanisms accordingly. Despite the theoretical attraction of some complex market-based mechanisms, simpler resolution mechanisms that afford quick resolution of outstanding debts, that improve financial system competitiveness, and that offer little discretion to governments are most effective.
\end{abstract}

\section{World Bank Policy Research Working Paper 3379, August 2004}

The Policy Research Working Paper Series disseminates the findings of work in progress to encourage the exchange of ideas about development issues. An objective of the series is to get the findings out quickly, even if the presentations are less than fully polished. The papers carry the names of the authors and should be cited accordingly. The findings, interpretations, and conclusions expressed in this paper are entirely those of the authors. They do not necessarily represent the view of the World Bank, its Executive Directors, or the countries they represent. Policy Research Working Papers are available online at http://econ.worldbank.org.

* Calomiris is the Henry Kaufman Professor of Financial Institutions at Columbia Business School and the Arthur Burns Fellow in International Economics at the American Enterprise Institute, Klingebiel is at the World Bank, and Laeven is at the World Bank and CEPR. We would like to thank Stijn Claessens, Augusto de la Torre, Tom Glaessner, Patrick Honohan, Randy Kroszner, Fernando Montes-Negret, Guillermo Perry, Tom Rose, and other participants at the World Bank conference on "Systemic Financial Distress: Containment and Resolution" for helpful comments and suggestions, and Guillermo Noguera for excellent research assistance. Email addresses:

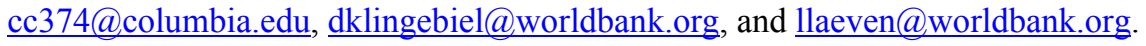




\section{Introduction}

Systemic financial crises are an extreme form of financial collapse that results in wealth destruction that cripples the financial system and magnifies economic decline. Initial declines in economic activity that begin as a normal recession become larger as those losses result in large exchange rate movements and collapses of banks. Exchange rate depreciation results in the loss of borrowers' wealth when debt is denominated in foreign currency. Furthermore, depreciation raises nominal interest rates on all loans, and results in adverse relative price movements for nontradables. Declines in borrowers' income and net worth destroy bank net worth. Additional bank losses may result from banks' direct exposure to interest rate and exchange rate risk.

In the frictionless neoclassical world, the allocation of wealth has no effect on the allocation of investment capital. But in the real world, wealth reallocations matter because the wealth of borrowers and banks plays an important allocative role in financial markets. The destruction of the net worth of borrowers and banks leads to a collapse of the loan market (Keynes 1931, Fisher 1933, and Bernanke 1983). The loss of borrowers' net worth reduces or eliminates their capacities to borrow, and often results in financial distress. The declines in the value of real estate and other assets relied upon for bank collateral have especially adverse consequences for the ability of SMEs and non-tradables producers in emerging markets to access funds since those producers have less access to funding sources outside their countries.

Declines in banks' net worth, which can result in bank failures, reduce or eliminate banks' abilities to supply loans. At a minimum, declines in banks' net worth will trigger increases in their funding costs, to the extent that banks rely on the willingness of market participants to fund their lending activities. Declines in net worth may also hamper banks' 
ability to restructure assets and work out non-performing loans as this may require banks to recognize further losses, which could trigger adverse regulatory or market reactions.

Institutional weaknesses are a further complicating factor in crises, many of which likely contributed to the emergence of the crisis in the first place. Institutional weaknesses contribute to the inefficient allocation of capital and the poor management of risk within the financial sector prior to the crisis. After the crisis, weak legal and regulatory institutions hamper the restructuring process by making it more difficult to address and resolve insolvency problems. Disclosure and accounting rules for financial institutions and corporations may be weak. Equity and creditor rights may be poorly defined or weakly enforced. The judicial system is often inefficient or corrupt. Under these circumstances it is difficult for creditors and debtors to reach agreement on workouts, for balance sheets to be rebuilt, for desirable transfers of ownership of firms or banks to take place, or for new suppliers of credit to be willing to enter the market.

In principle, the goals of financial restructuring are to reestablish the creditor-debtor relationships upon which the economy depends for an efficient allocation of capital, and to accomplish that objective at minimal cost. To limit the economic costs of a protracted financial crisis, governments have employed various crisis restructuring mechanisms that are aimed at restoring banks' financial health and/or at restructuring the balance sheets of the financial institutions' borrowers.

This paper reviews the taxonomy of resolution mechanisms that governments have employed in resolving financial crises and examines the benefits and costs of various alternatives, as well as the prerequisites necessary for successfully applying various policy measures, including the institutional quality of the country. 
Central to identifying the best policy approaches is the recognition that policy responses that reallocate wealth toward banks and corporate debtors and away from taxpayers face a key tradeoff. Such reallocations of wealth can help to restart productive investment, but on the other hand, such assistance entails two kinds of costs. Direct costs include the taxpayers' wealth that is spent on financial assistance. Indirect costs from financial assistance include misallocations of capital and distortions to incentives that may result from encouraging banks and firms to abuse government protection. Those distortions may worsen capital allocation and risk management after the resolution of the crisis. For example, some approaches to assistance (e.g., repeated debt forgiveness) may have a crippling effect on the future development of credit markets, and thus can be counterproductive. Countries with strong institutional environments will be better able to limit moral hazard related to specific policy measures. To analyze these issues, we will rely on a case study approach to measure the extent to which various policy tools met their objectives, the direct costs of these programs, and the extent to which they were "incentive compatible".

We find that countries typically apply a combination of tools to restructure their financial and corporate sectors, including decentralized, market-based mechanisms and governmentmanaged programs. Market-based strategies seek to strengthen the capital base of financial institutions and/or borrowers to enable them to renegotiate debt and resume new credit supply. Government-led restructuring strategies often include the establishment of an entity to which non-performing loans are transferred or the government's sale of financial institutions, sometimes to foreign entrants. Market-based mechanisms can, in principle, resolve coordination problems countries face in the wake of massive debtor and creditor insolvency, with acceptably low direct and indirect costs, particularly when those mechanisms are effective in achieving the desirable objective of selectivity (i.e., focusing taxpayer resources on borrowers and banks that 
are worth assisting). But these mechanisms depend for their success on an efficient judicial system, a credible supervisory framework and authority with sufficient enforcement capacity, and a lack of corruption in implementation. Government-managed programs may not seem to depend as much on efficient legal and supervisory institutions for their success, but in fact these approaches, in particular, the transfer of assets to government-owned asset management companies, also depend on effective legal, regulatory, and political institutions for their success. Asset management companies may not achieve their objectives of resolving the overhang of corporate debt at reasonable cost when legal and political institutions are weak. Further, a lack of attention to incentive problems when designing specific rules governing financial assistance can aggravate moral hazard problems, unnecessarily raising the costs of resolution. These results suggest that policymakers in emerging market economies with weak institutions should not expect to achieve the same level of success in financial restructuring as other countries, and that they should design resolution mechanisms accordingly. Despite the theoretical attraction of some complex market-based mechanisms, simpler resolution mechanisms that afford quick resolution of outstanding debts, and that offer little discretion to government officials are found to be most effective.

The paper proceeds as follows. Section 1 briefly reviews the policy setting in which emergency and long-run crisis resolution policies are formed, and reviews the literature on the pitfalls of restructuring mechanisms for the corporate and banking sector. Section 2 presents a taxonomy of alternative resolution mechanisms, and examines case studies in which countries have applied various resolution tools. The case studies review the specific country circumstances and assess to what extent the resolution was successful in reaching its objectives at reasonable direct and indirect costs, including the costs of exacerbating incentive problems. At 
the end of each case study, we derive lessons for policy, comparing the objectives of the restructuring measure used with the outcomes, and analyzing the determinants of failure or success. Section 3 concludes by summarizing the main general lessons of the various cases.

\section{The Policy Setting}

It is useful to recognize the context in which policy responses to financial crises occur. Policy responses to crises naturally divide into immediate reactions in the heat of a crisis, and long-term responses after the end of the crisis, although immediate responses often remain part of the longrun policy response. Initially, the government's policy options are limited to those policies that do not rely on the formation of new institutions or complex new mechanisms. Immediate policy responses include debt moratoria, which prevent creditors and/or bank depositors from seeking repayment from debtors and/or banks. Debt moratoria of one kind or another have a long history; in the United States, their use dates back to the early $19^{\text {th }}$ century. Central bank or government lending to financial institutions or borrowers is an alternative emergency measure with a long history (Bagehot 1873).

Another common immediate response to crisis is to relax financial sector regulations (socalled regulatory forbearance) to permit banks to avoid the costs of regulatory compliance. For example, regulators often cease enforcing banks' capital requirements in order to allow banks

and their loan customers to avoid the costs of contractions in loan supply. Supervisors and regulators accomplish this by permitting banks to understate their problem loans or other losses, and thus overstate their equity capital. The use of forbearance is a more recent policy tool than debt moratoria or government lending, owing to the fact that forbearance is only effective in the presence of credible government protection of bank depositors, which is a relatively recent 
feature of financial systems. Without an explicit or implicit government safety net, depositors would have an incentive to concern themselves about bank solvency irrespective of government regulatory policy; decisions by the government to relax capital standards would have little effect on banks as private market discipline and market-determined minimum capital requirements would be the real constraints on bank behavior.

Forbearance, debt moratoria in the form of suspension of convertibility of deposits, and emergency government lending are motivated by adverse changes in the condition of banks. Banks suffering severe losses tend not only to see rising costs, but also to experience liability rationing, either because they must have contract deposits to satisfy their regulatory equity capital requirement, or because depositors at risk of loss prefer to place funds in more stable intermediaries (Calomiris and Kahn 1991 and Calomiris and Gorton 1991 and Calomiris and Mason 1997). Banks, in turn, will transmit those difficulties to their borrowers in the form of a contraction of credit supply. Credit will become more costly and financial distress of borrowers and banks more likely.

In theory, emergency actions of all three types (suspension of convertibility of deposits, government loans, and forbearance) may alleviate the distress of banks and the contraction of credit supply. Debt moratoria that limit bank collections from their debtors may alleviate the distress of borrowers, which can also be beneficial to banks (if the moratoria limit fire-sale losses that result from asset liquidation) (Diamond and Rajan 2001).

But debt moratoria that help borrowers may hurt banks, and can poison future loan supply, as has been the case in Mexico after 1995. Unless a debt collection moratorium for borrowers is combined with measures that assist banks (loans, forbearance, or deposit suspension), debt forgiveness will put additional adverse pressure on banks and limit the supply 
of new credit. Assistance to banks in the form of deposit suspension, a reduction in the real value of deposits, government loans to banks, or capital regulation forbearance may permit distressed banks to continue accessing funding sources that underlie the supply of bank credit. The longterm consequences of debt forgiveness for credit supply depend on the way it is done: it can either help both banks and borrowers, or hurt banks and future borrowers while helping some of today's borrowers. The effects on depositors also depend on the way debt forgiveness is financed. If losses from debt forgiveness are financed in part by the government, then it is important to recognize that depositors are taxpayers too. We discuss the costs and benefits of debt forgiveness further below using the Civil War and the Great Depression in the U.S. as examples.

Despite the advantages from assisting banks, in theory, empirical research has found that the effects of providing assistance to banks and their borrowers can be counterproductive, resulting in increased losses to banks, which often abuse forbearance to take unproductive risks at government expense. The typical result of forbearance is a deeper hole in the net worth of banks, crippling tax burdens to finance bank bailouts, and even more severe credit supply contraction and economic decline than would have occurred in the absence of forbearance (Demirguc-Kunt and Detragiache 2000, Honohan and Klingebiel 2003, Claessens, Klingebiel and Laeven 2003).

Financial collapse can also have long-term consequences for the structure of the legal enforcement of creditors' rights, which can undermine the ability of healthy banks to lend to healthy borrowers. In extreme circumstances, when most borrowers and banks are insolvent as the result of changes that have occurred in their net worth, the legal rules governing banks and borrowers, or the enforcement of those rules, often change suddenly. Emerging markets' legal 
systems tend to have weaker enforcement of creditors' rights even during good times (La Porta, Lopez-de-Silanes, Shleifer and Vishny 1998). But when crises strike, and debtor insolvency becomes the rule rather than the exception, enforcement of creditors' rights becomes even weaker as the result of actions by government and the courts.

For example, after the Mexican crisis of 1995, Mexico evolved what came to be called the "culture of no payment" in which few debtors paid their creditors and the courts were not inclined to come to the assistance of creditors in forcing payment. In this environment, banks were not repaid and borrowers continued operating for years with little certainty about what they will ultimately pay on their outstanding debt. The breakdown of the legal system has plagued many other crisis countries. Asian crisis countries similarly saw a lack of will on the part of courts to enforce bankruptcy laws that protected creditors' interests.

Once emergency measures have been put in place to contain the crisis, the government faces the long-run challenge of rebuilding the financial system, which entails the resumption of a normally functioning credit system and legal system, and the rebuilding of banks' and borrowers' balance sheets. Section 2 considers the long-run options available to the government from the standpoint of country experiences managing long-run crisis resolution.

\section{A Taxonomy of Crisis Resolution Mechanisms}

Here we discuss seven types of crisis resolution mechanisms, which we analyze through case studies where these policies were applied. We examine the extent to which policies met their respective objectives and draw more general lessons from the country cases. As financial crises are typically characterized by distress of both financial institutions and corporations, ideally, a 
resolution mechanism should not only result in bank restructuring, but also achieve corporate restructuring and vice versa.

We include the following seven policy choices in our analysis: (capital) regulatory forbearance, across-the-board incentives for loan loss write-offs, conditional governmentsubsidized workouts of assets, debt forgiveness, the establishment of a government-owned asset management company, government-assisted sales of financial institutions, and governmentassisted recapitalization. While other resolution mechanisms have been employed by countries in the past, most of these can be considered modifications of one of the above seven types of resolution mechanisms. For example, an outright nationalization of banks can be considered an extreme case of a government-assisted recapitalization of financial institutions. The seven resolution mechanisms under consideration cover the vast majority of government policies that have been employed.

\subsection{Forbearance}

Forbearance from prudential regulations, as we have already discussed, essentially allows for the delay in the recognition of loan losses (or capital shortfall) and is aimed at providing financial institutions with time to recapitalize on a flow basis from current earnings. It is usually a policy adopted during the heat of the crisis, and may be continued as part of the long-run resolution strategy, often because of the difficulty of bringing an end to forbearance policy once banks have become massively insolvent. Governments do not generally pursue forbearance as a preferred long-run resolution tool for financial crises, rather they stumble into it as the result of exigencies and a lack of attractive alternatives. Forbearance can be characterized as providing government protection to banks without the discipline of prudential regulation - an approach to long-run 
financial policy that few governments would consciously choose, and none would admit to choosing (it might be better described as the absence of a policy). As an example of long-run forbearance policy, we consider the U.S. Savings and Loan crisis of the 1980s.

\section{The Savings and Loan Crisis in the United States}

Federally chartered thrift institutions operating in the United States in the 1970s complied with different regulations than banks, and were supervised by the Federal Home Loan Bank Board. Their activities and range of permissible investments were circumscribed by strict regulations, which effectively required them to engage in a colossal maturity mismatch, holding 30 -year fixed rate mortgages as their primary asset and financing themselves with savings accounts that could be withdrawn at any time. The rising inflation of the 1970s, and the monetary policy reaction to that inflation post-1979 by the Federal Reserve Bank, produced a surge in interest rates that resulted in enormous losses of net worth (on a market value basis) for thrifts over the years 1979-1982. Many thrifts were insolvent on a tangible capital basis by 1982 (Barth and Bartholomew 1992).

The initial reaction to the thrift debacle was to broaden thrift powers (to permit them to engage in a broader range of activities, including the purchase of junk bonds, and involvement with derivatives contracts) and to change thrift accounting practices so that insolvent thrifts would be treated as though they were still solvent. The new breed of insolvent, deregulated thrift would now be able to invest in risky assets such as junk bonds, raise (insured) funds on the brokered CD market to finance rapid growth, and be able to engage in derivatives contracts, without any concern that its true (insolvent) circumstances would limit its ability to grow and prosper. 
Underlying this initial policy response were two important incentive problems in the government. First, the thrift industry - which had been losing market share to new forms of financial intermediation for the previous quarter of a century - had "captured" its government regulator, the Federal Home Loan Bank Board. Thrifts and their regulator alike were fighting for the survival of "their" industry and jobs, and phony accounting gimmicks and new opportunities to make money quickly seemed to be the only way out. Second, Congress and the Administration had little incentive to force thrifts and the Federal Home Loan Bank Board to recognize thrift losses, since doing so would force the recognition of enormous losses, and lead to the taxpayer financed recapitalization of the Federal Savings and Loan Insurance Corporation (FSLIC). That was a step few politicians in Washington were in a hurry to take in the early and mid 1980s.

Forbearance via phony accounting, combined with deregulation of thrift powers, gave insolvent thrifts the time and flexibility they needed to attempt "resurrection" via a combination of fast growth and higher asset risk. Deposit insurance acts like a put option for insured institutions (Merton 1977), and the value of that option rises with asset risk in a way that is dependent on the solvency of the thrift. For solvent thrifts, the option value of increasing risk is low, and is probably offset by the disutility of increasing the riskiness of the payoff to the equity holder. For insolvent thrifts, the option value of increasing risk is much higher, and since there is little chance or surviving without earning very high profits, little is lost by betting on resurrection. The incentives to increase risk when deposits are insured is often referred to as the moral hazard problem of deposit insurance. Brewer (1995) tests the Merton model of moral hazard for thrifts in the 1980s and finds strong evidence for the view that the combination of 
forbearance and deposit insurance encouraged thrifts to increase their risk, and ultimately their average losses, substantially.

As estimated losses among thrifts continued to rise - reaching some $\$ 200$ billion in prospective losses as of 1988 - so did the threat of a political backlash against thrifts, their regulators, and political supporters. With the passing of the electoral and budgetary cycles of 1988, the political incentives shifted toward recognition of loss and institutional reform. Forbearance was out; regulatory discipline was in. The Federal Home Loan Bank Board was abolished and replaced with the Office of Thrift Supervision (OTS), which soon became the most aggressive enforcer of loan loss recognition in U.S. history. The OTS, FSLIC, and Resolution Trust Corporation moved speedily in combination to force thrifts to recognize losses, shut down if insolvent, and have their assets liquidated in the market. What ensued was one of the fastest processes of en masse real estate asset liquidation that has ever occurred.

\section{Lessons From the Case Study}

As the above analysis shows, forbearance did not result in an improvement of S\&L's balance sheets, but rather, encouraged weakly capitalized financial institutions to gamble for resurrection and increase loan losses. In addition, the restructuring of bank balance sheets did not take place during the forbearance period, as weakly capitalized banks did not have the incentive or the ability to raise enough capital to engage in any meaningful restructuring. Thrifts were encouraged by forbearance to pretend that they were healthy as they desperately tried to grow and bet their way out of their illness.

The U.S. thrift case, along with numerous empirical studies that generalize its lessons (Calomiris 1989 and Hovakimian, Kane, and Laeven 2003) show that forbearance by itself 
cannot effectively deal with system-wide bank problems and therefore cannot act as an effective resolution mechanism.

Because forbearance cum deposit insurance is exploited disproportionately by deeply insolvent institutions (which presumably are also the ones that are least worth saving), and because that exploitation can be extremely costly for taxpayers, forbearance is a very wasteful means of channeling taxpayer wealth toward rebuilding the financial system. A mechanism that would subsidize the rebuilding of bank capital selectively within the best banks could be far less costly and would accomplish much more in the way of efficient credit allocation in the future than forbearance policy. We discuss this point more fully below when considering the U.S. experience with preferred stock assistance during the 1930 s.

\subsection{Tax Incentives for Loan Loss Write-Offs}

A second resolution technique provides incentives to financial institutions to engage in and/or accelerate corporate restructuring in the form of tax subsidies for loan write offs or other similar forms of subsidies. Since this approach leaves actual restructuring to banks and corporations, it is a market-based and decentralized approach to corporate and bank restructuring. As an example of incentives for loan loss write-offs, we consider the case of Japan in 1992.

\section{Loan Loss Write-Offs in Japan}

The Japanese banking crisis of the 1990s is unlike the other financial crises studied in this paper in the sense that there was no sudden crisis but rather a prolonged, steady deterioration in the health of Japan's financial system. This prolonged crisis resulted from a combination of 
inadequate disclosure of information on the true financial condition of financial institutions, and the slow response to the crisis by the government.

In 1992, when it became clear that Japanese banks had a large amount of nonperforming loans, mainly in the construction and real estate sectors, the Credit Cooperative Purchasing Company (CCPC) was set up to transfer bad real estate loans of member banks. The main advantage for banks of utilizing the CCPC to write-off loans was that the claimed losses on loans sold was deductible from taxable income. Until 1992, the write-off of bad debts against taxable income had not been allowed, at least not until an actual bankruptcy procedure against the borrower began. However, due to the mounting problems in some of the major financial institutions in Japan, such deduction from taxable income was approved by the tax authorities.

In the years that followed, further tax policy changes were announced to make it even easier and more attractive for banks to deduct loan losses for tax purposes. Hence, rather than directly recapitalizing banks and addressing the bad loan problem using public funds, initially the Japanese government relied on tax incentives for recognition of loan losses to solve the bad loan problem.

Almost all banks took advantage of these tax incentives and liberally deducted losses on loans to assist related, troubled borrowers and on loans transferred to the CCPC (Packer 2000). Despite the "success" of the CCPC program in transferring large amounts of bad loans, the main problem was not attacked, and bad loans continued to rise, as new non-performing loans replaced those that were previously written down, and the condition of financial institutions continued to deteriorate. Although the government continued to allow banks to write off bad debts against taxable income, loan losses were not recognized in the amount necessary, as a lax accounting regime did not force financial institutions to recognize losses. 
Despite the tax incentives offered, banks remained reluctant to recognize the full extent of loan losses. One reason is that asset deflation combined with explicit deposit insurance made loan loss write-offs unattractive. Furthermore, the historical absence of liquidation procedures and limited capacity of the bankruptcy court system made orderly liquidation even more challenging (Packer and Ryser 1992). The continuing growth in non-performing loans reflected further deterioration in asset values as well as previously unrecognized earlier losses.

The initial strategy of Japan's authorities of relying on tax breaks to assist banks failed to restore the health of the banking system. Financial institutions seriously lacked incentives to engage in effective corporate restructuring as they were allowed to continue to hide their losses and operate with a weak capital base. This resulted in moral hazard behavior by banks and bank borrowers, which was exacerbated by a government guarantee on all bank deposits. Additionally, the Japanese Keiretsu model, in which Japanese banks have close relationships with affiliated firms and Japanese banks own substantial equity positions in those firms, further reduced market discipline and incentives to attack the mounting bad debt problem, and encouraged banks to use government subsidization of losses largely as a means to assist related enterprises (Sheard 1989 and Peek and Rosengren 2002).

\section{Lessons from the Case Study}

The potential advantage of loan loss write-offs is that loan losses are recognized quickly. Speedy recognition is desirable because it encourages the strengthening of the equity capital positions of financial institutions, and because it reinforces the credibility of accounting rules and capital regulation, and thus disciplines risk taking by discouraging banks from undertaking high-risk resurrection strategies. Credible regulation and accounting rules also facilitate the rebuilding of 
equity by making the financial statements of banks more reliable to potential outside investors. Loan loss write-offs do not directly address the problem of improving debtor capacity, as corporate restructuring is left to the market. Often, a clean up of banks' balance sheets is, however, a first step in the direction of restarting corporate lending on a sound market basis.

Among the costs of subsidizing loan loss write offs, however, is the incentive cost from channeling taxpayer support to banks and their borrowers, and thereby relieving them of some of the cost of having engaged in unprofitable lending and borrowing. By not imposing losses on corporate borrowers, banks' shareholders, and depositors loan loss write-off subsidies worsen incentives for prudent behavior. Also, as in the case of forbearance, an across the board subsidy for all bank loans may create an adverse selection problem, because the amount of subsidy is likely to be inversely related to the soundness of the financial institution or borrower receiving the subsidy. This results in both poor incentives and a waste of scarce taxpayer resources, which might be better channeled to support the selective rebuilding of the balance sheets of the best banks and bank customers (see the discussion below of the Reconstruction Finance Corporation's experience in the 1930s). In Japan the adverse selection problem was even worse, since banks faced little incentive to undertake across-the-board write offs, but did see value in using subsidized write offs to assist distressed related firm borrowers.

The Japanese experience of the mid-1990s is representative of how forbearance fails to give incentives to restructure bad loan portfolios and of how principal-agent problems in asset resolution are exacerbated in a system where banks and their borrowers have ownership links, and where the government issues a blanket guarantee on all deposits. Finally, the Japanese case illustrates that loan loss write-offs are unlikely to be an effective resolution mechanism in systemic financial crises because the subsidy may not be sufficient to cover the capital shortfall 
experienced by the banks, and because banks may lack incentive to take full advantage of the program being offered. As in the case of forbearance, for loan loss write-offs to be an effective resolution mechanism, they must be combined with other tools, which ensure that banks will make proper use of the assistance they are being given from the government. These include (i) a credible supervisory authority with sufficient enforcement capacity to encourage financial institutions to recognize losses and engage in corporate restructuring, (ii) an efficient bankruptcy system to solve coordination problems between debtors and creditors, and allow corporate restructuring to occur, and (iii) a high-quality accounting framework that makes it hard for banks to mask non-performing loans. In Japan, all of these elements were lacking and banks had little incentive under these circumstances to take advantage of government subsidies for loan loss recognition; they believed they were better off delaying recognition of losses, taking advantage of Japanese regulators' forbearance policy and hoping for a reversal of their losses.

\subsection{Conditional Taxpayer Sharing of Loan Losses}

The third resolution approach - which is similar in many ways to the second approach, and is also a decentralized market-based approach - is a workout program for non-performing loans in which the government shares directly in the loan losses experienced by the lender, but requires as a condition for government subsidies that bank borrowers contribute to loan resolution, as well. As an example of government sharing of loan losses, we consider the Punto Final Program in Mexico. 


\section{The Punto Final Program in Mexico}

For three years, the FOBAPROA program initiated in 1995 had failed to reduce the amount of past due loans and to provide debtor relief (see case study in section 2.5). In a final attempt to offer debt relief, the government initiated in December 1998 the Punto Final program, which was a government-led debt-relief program targeted to mortgage holders, agribusinesses, and small and medium-sized enterprises (SMEs). The program offered large subsidies (up to $60 \%$ of the book value of the loan) to bank debtors to pay back their loans.

The Punto Final program consisted of three debtor-relief programs that were directed toward mortgage holders, the rural and fishing sectors, and enterprises. The discounts depended on the program, the amount of the loan, and on whether the bank restarted lending to the sector. Large loans only received discounts up to a certain amount. The government would increase its share of the discount offered according to the following rule: for every three pesos of new loans extended by the bank, the government would assume an additional one peso of discount. Only new loans to individuals and small and medium-sized enterprises would qualify for counting toward receiving this additional government subsidy. The program thus combined loss sharing between the government and the banking sector with an incentive to restart lending (World Bank 2003).

Although both the Punto Final program and the FOBAPROA program combined an element of loss sharing between the government and the financial institutions, there were four key improvements of the Punto Final program vis-à-vis its predecessor. First, loss sharing was geared toward small loans, as the discount offered was higher for smaller loans. Small borrowers are a desirable group to target, since assisting them improves competition in the economy, and since assistance channeled to these borrowers is less likely to result from their political or 
economic power over governments or financial institutions. Second, the loss sharing arrangement offered an incentive for banks to restart lending to SMEs and individuals because it linked the size of government assistance to the amount of new lending by the participating bank. Third, the program may have made more effective use of taxpayers' resources, because it relied on borrowers' willingness to participate, and it required borrowers to pay part of their outstanding loans. Borrower self-selection, in principle, can reduce the number of participating borrowers, and reduce taxpayers' cost of resolution per borrower by requiring borrowers to repay part of their loans. Just as important, self-selection may ensure that participants are more likely to be those that were "worth helping." The borrowers willing to repay part of their loans should be those that value access to credit in the future, which also tend to be more value-creating borrowers. The FOBAPROA program, in contrast, had not been selective, and had greatly benefited large borrowers at high cost to taxpayers, irrespective of the desirability of assisting them, and even if those borrowers were not in default. Fourth, unlike its predecessor, the Punto Final program offered to quickly resolve ongoing disputes between creditors and debtors, and thus made it easier to analyze the balance sheets of participating borrowers and banks going forward. Resolving the uncertainty about how much of their preexisting debts would be repaid is a key requirement for analyzing the balance sheets of borrowers when making new loans. Debt resolution, in theory, should help to make credit available to creditworthy firms.

Despite these potentially attractive features, it would be premature to declare the Punto Final program a model of successful restructuring. One criticism is that it was restricted to too limited a class of borrowers. Despite the advantages of selectivity, it might have been desirable to extend the program to more firms and individuals. Furthermore, the effectiveness of the program in corporate restructuring was plagued by many of the same institutional weaknesses as 
those that hampered its predecessors. Those included the lack of a credible supervisory authority with sufficient enforcement capacity to incentivize financial institutions to recognize losses and engage in corporate restructuring, the lack of an efficient bankruptcy system (which provides a threat that banks can use to encourage borrowers to participate in voluntary loan work outs), and the presence of politically-connected lending in an environment where politicians, business groups, and banks are intertwined, and seek mutual advantage at the expense of taxpayers.

It is difficult to assess the effectiveness of the Punto Final program, not least because it was preceded by, and coincided with, numerous other financial support and debtor relief programs. After all, the Punto Final program, as its name indicates, was intended to finalize the bailout of the banking sector and the debtor relief program in Mexico. There were also other positive developments - growth, increased banking sector income, and foreign entry into banking - which improved the condition of banks and the supply of credit during this period.

Nevertheless, despite the difficulties of attribution, we note that the banking system did show some improvements in indicators of asset quality, profitability, and capital adequacy during the years 1997-2000, and that Punto Final may have played a role in those improvements. At the end of 2000, almost all banks complied with the minimum requirement of 8 percent of riskweighted assets, with an average capital adequacy ratio (excluding intervened banks) of about 14 percent. Return on average assets has increased from close to zero in 1995 to 0.9 percent in 2000, but is still low and there is substantial variance in profitability across banks. Indicators of asset quality have improved as well over recent years. For example, past due loans to total loans excluding FOBAPROA decreased from 17.6 percent in 1997 to 8.5 percent in 2000. The improvements in asset quality largely reflect the conclusion of debtor relief programs through the Punto Final program (IMF 2001a). 
However, even with additional debt relief offered under the Punto Final program, bank lending did not restart as expected. Bank credit to the private sector has contracted from about 19 percent of GDP at end-1998 to 10 percent of GDP at end-2000. The lending environment during this period continued to be negatively affected by the difficulty banks face in repossessing collateral or receiving fair treatment in bankruptcy. The ratio of repossessed collateral to total loans excluding FOBAPROA has remained fairly stable during the period 1997-2000 increasing only slightly from 1.5 percent in 1997 to 1.7 percent in 2000 (IMF 2001a). However, Mexico has since made significant progress in improving its bankruptcy framework and asset resolution process, and repossession of collateral has become easier.

\section{Lessons from the Case Study}

The conditional sharing of loan losses can help achieve the recognition of loan losses by banks, can clean up borrowers' and banks' balance sheets, and indirectly can improve the capital base of financial institutions by encouraging loan repayment. Also, since banks share in the loan losses, it offers incentives for banks to engage in corporate restructuring and therefore may indirectly improve debtor capacity. The selectivity that comes from conditional programs like Punto Final can result in better targeting of taxpayer resources toward borrowers that were worth saving, because of the type of borrowers that will self-select into the program. In the case of Punto Final, resource savings and effectiveness probably were enhanced by the fact that the program focused primarily on SMEs and other small borrowers, which are less likely to be entwined in the too often corrupt iron triangle of banks, conglomerates, and government officials. Furthermore, by linking assistance to new credit supplied by banks, the Punto Final program helped to further its goal of restarting the credit supply process more than an across-the-board subsidization of write 
downs would. Finally, because conditional subsidization requires borrowers to share somewhat in the costs of financial sector subsidies, the adverse incentive effects of these subsidies for future borrowing and lending behavior will be less than for unconditional subsidies of write downs. For all of these reasons, conditional subsidization of loan losses through a program like Punto Final seems superior to across the board subsidization of loan write downs by banks, as in the Japanese case.

On the other hand, there are three major limitations to applying the Punto Final model as a resolution strategy. First, the successful implementation of selectivity still depends on the efficiency of the legal system to encourage participation. The incentive of borrowers to participate depends both on the stick of the enforcement of creditors rights and the carrot of future credit supply (which in turn depends on the existence of creditors rights). Mexico's implementation of Punto Final coincided with a complete reform of the bankruptcy process and the laws for perfecting collateral interests. Although those initiatives were still ongoing at the time, both borrowers and lenders had reason to believe that creditors rights were being boosted in the future, and that both the carrot and the stick available to creditors were getting bigger.

Second, to the extent that selectivity creates potential for corruption in allocating subsidies, selectivity is less desirable. We were unable to undertake a microeconomic analysis of the Punto Final program to determine the extent to which the allocation of assistance was executed fairly and efficiently owing to a lack of available data. That lack of data, in part, seems to reflect the political climate of Mexico and the political controversies that surround debt relief programs. Ironically, without proper disclosure and the opportunity to analyze the use of government funds, it will continue to be difficult for the Mexican public or academic researchers to have confidence in the appropriateness of the disposition of taxpayer resources. 
Third, if the goal is a large-scale restructuring of the financial system, the microeconomic advantages of selectivity must be traded off against the macroeconomic advantages of large-scale improvements in corporate debt capacity and bank net worth. For that reason, to be effective, the Punto Final model would have to be applied to a significant share of the population of borrowers (not just SMEs). The strengths of Punto Final, however, are mainly confined to assistance to SMEs, where concerns about corruption in the implementation of selectivity, and concerns about inefficient use of resources to prop up powerful conglomerates may not be as great.

Finally, we note that conditional subsidies and across-the-board write down subsidies share some of the same limitations. Neither approach distinguishes among banks with respect to the allocation of assistance. Indeed, banks that made the worst lending decisions prior to the crisis will receive the most assistance after the crisis. Thus neither approach does much to address the adverse-selection and moral-hazard problems of providing assistance to insolvent banks.

Another common feature, and weakness, is that both subsidization approaches depend for their success on the legal and regulatory context in which the subsidies are offered, and especially on (i) a credible supervisory authority with sufficient enforcement capacity to provide incentives for financial institutions to recognize losses and engage in corporate restructuring and (ii) an efficient legal system for enforcing collateralization and other lending laws, including a bankruptcy system to encourage corporate restructuring to occur. Without the first element, banks may prefer not to pursue restructuring, and without the second, neither banks nor borrowers may see the same incentives to resolving their debts and entering the market for new credit. 


\subsection{Debt Forgiveness}

This approach uses some combination of legal innovations, the government's power to determine the numeraire and medium of exchange, and/or taxpayer resources to change the value of corporate and/or bank debts or to forgive part or all of borrowers' and/or banks' debts. The objective of debt forgiveness is to reduce the debt overhang problem, and improve the repayment capacity of bank borrowers and banks. Debt forgiveness results in an across the board corporate and banking system restructuring.

As examples of debt forgiveness programs we consider the suspension of gold convertibility in the United States from December 1861 until January 1879, and the abrogation of the gold standard and gold payment clauses in debt contracts in the United States in the 1930s, both of which involved substantial changes in laws and monetary arrangements to achieve their desired results with no fiscal cost to the government.

\section{The Legal Tender Bailout of Debtors and Banks during the U.S. Civil War}

The U.S. Civil War, which began in March 1861, had created an unexpected surge in the financing needs of the Union. An initially unsuccessful campaign to raise funds at low cost was rescued by the actions of a consortium of banks from the major Eastern cities in the fall of 1861, which intended to distribute the securities to other investors over the course of the ensuing months. Unfortunately, for those bankers, the December 1861 Report of the Secretary of the Treasury shocked financial markets with its (realistic) view of war expenditure needs and with the Secretary's decision not to seek large additional tax increases. Government debt markets were also depressed by the growing risk of a war with Great Britain. Government debt prices 
fell and the money center banks, which were still holding a massive amount of the government debt that they had just purchased, were suddenly exposed to the risk of insolvency and bank runs.

The immediate solution was a suspension of convertibility of private bank notes and deposits into gold (the standard of value at the time). The longer-term solution (adopted in February 1862 and envisioned to last as long as wartime finance depressed the value of government debts) was to change the numeraire of the economy from gold to a new form of fiat government currency issue, known variously as U.S. notes, treasury notes, legal tender notes, or greenbacks. The legal tender act also created a new financing option for the government, which would rely upon currency issues to fund a large fraction of its wartime expenditures. Thus did the United States embark on its first experiment with legal tender fiat currency, despite the fact that many observers doubted the Constitutional power of the government to issue such currency or to make it a legal tender for the settlement of private dollar-denominated debts. By redenominating bank debts into the same depreciated numeraire as bank assets (i.e., government securities), banks' solvency was restored and the financial crisis was resolved. The use of legal tender currency to end the crisis within the banking system was a conscious goal of the legislation (Mitchell 1903 and Hammond 1970).

Creditors and depositors suffered from the depreciation of their claims that resulted from the depreciation of the dollar, but the dollar's depreciation was temporary; by the end of 1866 , the dollar had returned to roughly $80 \%$ of its prewar value. In the meantime, depositors and creditors had gained from the avoidance of massive borrower insolvency and bank failures, which surely would have produced significant adverse macroeconomic consequences. In the event, the early 1860s were a time of prosperity for the U.S. economy (Burns and Mitchell 1946). 
Did the legal tender acts undermine the credibility of the U.S. financial and legal system? The long-term costs of the bailout seem to have been negligible. Although inflation risk continued to be a problem in the U.S. because of the risk of a further change in the monetary standard until the Gold Standard Act of 1900 (Calomiris 1993b), the effects on interest rates were mild, and the late-nineteenth century was a time of growth.

The legal tender acts were not reversed immediately after the War, although the government continued to promise an eventual return to gold convertibility at the prewar parity. The constitutionality of legal tender laws was upheld by the courts. President Grant packed the Supreme Court with legal tender advocates to ensure that the Court would not declare the law unconstitutional. Government currency thus became a permanent component of the money supply. Over time, it became increasingly evident that the use of the legal tender acts had been an exceptional act to deal with exceptional circumstances, which may explain why the long-run consequences of the devaluation were so small. The resumption of gold convertibility was achieved on January 1,1879, requiring that greenbacks be convertible into gold at the prewar parity.

\section{The Suspension of the Gold Standard and Abrogation of Gold Clauses in the U.S.}

Over the past decade, it has become a matter of widespread agreement that worldwide deflation under the gold standard propelled the world into Depression in the 1930s (Temin 1989 and Eichengreen 1992). An important channel through which deflation promoted depression was the rising real value of debts (Keynes 1931, Fisher 1933, Bernanke 1983, and Calomiris 1993a). As real debt values rose, borrowers became insolvent and were unable to meet fixed debt service from shrinking cash flows. Defaults on bank loans produced bank distress, further worsening the 
ability of the financial system to allocate funds properly. Wicker (1996) and Calomiris and Mason (2003b, 2003c) find that bank distress in the U.S. in the early 1930s was largely a consequence of loan loss problems, rather than liquidity crises per se, and that bank distress was important in deepening the Depression.

President Roosevelt's interest in gold devaluation did not originate from a belief that debt deflation and its effects on credit supply had exacerbated the Depression. Rather, his interest in the gold value of the dollar was primarily linked to his view that raising commodity prices, per se, was crucial to economic recovery. Presidents Hoover and Roosevelt both subscribed to the (now discredited) view that policies that kept wages and prices higher would lead to higher incomes. Despite Roosevelt's initial assurances to the markets that he would not devalue the dollar, by May of 1933 he had reversed course, and had received authority from Congress to devalue the dollar with respect to gold. The retreat from unqualified support for the gold standard produced gold outflows and a decline in the value of the dollar.

There was, however, a hitch in the Administration's plan to devalue the dollar to reflate incomes. Unlike the situation in 1861 (indeed, because of the policies that had been implemented in 1861) the structure of debt contracts had changed toward the use of gold clauses - contractual protections against devaluation of the dollar that preserved the gold value of nominal debt. The change in the numeraire of private debts and bank deposits during the Civil War had been achieved by establishing a new Constitutional right of the government to redefine the meaning of the dollar. The courts ultimately upheld the government's view that the Constitution granted the federal government both the right to define the value of the dollar and to issue legal tender notes.

One of the long-term consequences of this new breadth of government power over the definition and supply of dollars was the use of gold clauses in both private and public debt 
offerings. Gold clauses eschewed the use of the dollar as a unit of value, and in so doing, intended to preserve the value of debt obligations no matter what monetary standards the government might adopt for the dollar. Issuers employed gold clauses to eliminate an inflation risk premium from the cost of debt service, and the courts consistently ruled that private parties could use gold clauses to avoid the risk of legal tender changes in the value of the dollar (Kroszner 1999). Virtually all long-term corporate debt contracts and many mortgages in existence by the 1930s contained gold clauses (Macaulay 1938 and Friedman and Schwartz 1963).

The problem for Roosevelt's devaluation strategy was that devaluation would reduce the gold value of income relative to the gold value of debt service (preserved by gold clauses) and risk massive insolvencies for debtors as the result of devaluation. The Administrations' response to this conundrum was to try, once again, to establish new Constitutional rights - this time, the federal government's right to forbid transacting in gold and its right to abrogate existing gold clauses in private debt contracts. On June 5, 1933, Congress passed a Joint Resolution declaring gold clauses unenforceable and "against public policy" (Kroszner 1999), and allowing golddenominated debt obligations to be paid at face value in dollars. During the ensuing months Roosevelt also acted to devalue the dollar by even more than he had been authorized to do in May 1933.

The abrogation of gold clauses, which amounted to a $69 \%$ reduction in the value of firms' outstanding debts, was greeted with revulsion by many defenders of the sanctity of contracts, who decried the unconstitutional and unprecedented nature of the intrusion into private contracting. Legal battles raged, culminating on February 18, 1935 in the dramatic 5-4 decision by the Supreme Court, which found in favor of the constitutionality of gold clause abrogation. 
Kroszner (1999) analyzes the responses of various types of securities to the Supreme Court decision and finds that stock and bond prices went up when the decision was announced, and that bonds of firms facing the highest probability of bankruptcy gained the most. Kroszner interprets the increase in the market value of debts with gold clauses as an indication that the abrogation of the clauses raised the probability of repayment such that the value improvement from a higher repayment probability more than offset the depreciation in value from the change in the numeraire. From the standpoint of the debtholders, Kroszner argues, it was "better to forgive than to receive."

These results provide powerful evidence in favor of the usefulness of debt forgiveness as a means of solving coordination problems in renegotiating debt. Few individual creditors would have been willing voluntarily to remove gold clauses from the debts they held, but when all of them were forced to do so collectively, the improvement in aggregate economic circumstances made creditors and debtors better off. Similarly, the losses borne by depositors from depreciation in the value of deposits as the result of abandoning the gold standard were offset to some extent by the reduction in banking distress produced by currency depreciation.

Did the Supreme Court decision undermine investor confidence in the rule of law and in the stability of monetary policy and the value of the currency? Apparently not. Market participants seem to have understood that the Court's decision reflected the practical difficulties under the extreme circumstances of the Depression, and the threat posed by massive corporate bankruptcy, from doing otherwise. Growth continued at a fast pace from 1933 through the fall of 1937, waves of bank failures ceased, and the exchange rate and price level remained stable. 


\section{Lessons from the Case Studies}

By employing legal powers to bailout debtors, the 1861 and 1933 policy actions avoided any direct fiscal costs from the bailout. Of course, all bailouts are financed by someone. In the case of legally mandated reductions in the real value of debt, debtholders and bank depositors are the source of financing for debt reduction. But, as Kroszner (1999) shows, they may also be net beneficiaries of the policy if the favorable macroeconomic consequences of the bailout increase the probability that the obligations they are holding will be repaid. Furthermore, to the extent that creditors and depositors are taxpayers, one must consider the counterfactual costs depositors would have borne from alternative approaches to financing the bailout, which would have been substantial. In the cases we examined, the costs borne by creditors and depositors were mild, and perhaps on net, creditors and depositors benefited from the policies.

More generally, the advantages of debt forgiveness illustrated by these two cases are three: The first two advantages are effectiveness and speed of action in resolving corporate and banking sector problems. Debt forgiveness recognizes loan losses and deals with them, thus providing immediate relief to borrowers. It can also be a source of, and an encouragement of, the speedy rebuilding of bank balance sheets. Whether financial institutions' capital is strengthened depends upon the extent to which: (i) debt relief substantially improves the probability of loan repayment, (ii) depositor debts are also depreciated alongside bank loans (or subsidized directly by the government), and (iii) the government or financial institutions provide additional capital after losses are recognized. The third advantage of debt forgiveness is its simplicity, which makes it far less dependent on the quality of legal, regulatory, and political institutions than more complicated alternatives like AMCs or the Punto Final program. 
A disadvantage of debt forgiveness is that is does not impose losses on corporate borrowers and bank shareholders, therefore, it may create incentives for poor risk management by borrowers and banks. To the extent that debt forgiveness is only used in extreme circumstances (like the Civil War or the Great Depression), the moral hazard consequences from its use will be low, but if borrowers and bankers see governments as willing to employ this as a form of repeated countercyclical policy, borrower risk taking will increase. Another disadvantage is the undermining of monetary institutions and the rule of law that comes from repeal of monetary standards and interference in private contracting. Here, too, the costs will depend on the frequency of use and the extent to which the market believes that the government reserves such drastic measures for truly exceptional circumstances.

Moral hazard by bankers and borrowers and reputational costs to the government may be reduced by limiting the amount of forgiveness and linking it to the performance of the borrower or bank debtor receiving forgiveness. But this approach is not practical if debt forgiveness is achieved via an across-the-board change in the real value of debt. But the across-the-board reduction in the real value of debt via a change in the numeraire of debt may still be preferable, given that it does not impose a fiscal burden (which selective bailouts necessarily entail), and given the advantages of speed and simplicity from across-the-board forgiveness noted above.

However, for debt forgiveness to be fully successful in restarting the credit supply process on a sound footing, additional conditions are necessary, including an efficient legal and bankruptcy system in credit markets to give incentives to borrowers to continue to service the remainder of outstanding debt, and a supervisory framework that forces banks to take advantage of their improved circumstances by rebuilding their capital positions as need be. 


\subsection{Government-Owned Asset Management Company (AMC)}

The establishment of a government-owned and government-managed AMC involves the transfer of non-performing assets to a government asset management company. The objective of an AMC is to accelerate corporate restructuring. This mechanism adopts a government-based, centralized approach to corporate restructuring. As examples of government-owned AMCs, we consider the cases of Securum and Retrieva in Sweden, and FOBAPROA in Mexico. For a review of AMCs in a select number of other countries, see Klingebiel (2000).

\section{Securum and Retrieva in Sweden}

Liberalization of financial sector regulation in Sweden during the 1980s, without an appropriate strengthening of the regulatory and supervisory system, led to a lending boom that fueled a protracted real estate boom (Berggren 1995). From 1987 to 1990 total credit rose from 90 percent of GDP to 140 percent of GDP. During that period, under a fixed exchange rate regime, firms started to borrow in foreign currency to take advantage of lower foreign interest rates. At end-1990, more than 50 percent of outstanding corporate debt was denominated in foreign currency (Drees and Pazarbasioglu 1998).

Tax reforms in the late 1990s that decreased the tax deductibility of interest expenses on real estate investments, in combination with a tightening of monetary policy and lower inflation, raised real after-tax lending rates considerably and contributed to a sharp drop in property and share prices. As a result, Sweden entered a deep recession, which in turn accelerated asset price deflation. In addition, the crisis led to very high interest rates (up to 500 percent) and to a substantial depreciation of the Swedish krona when it started to float in 1992. 
Both developments considerably undermined the capability of many borrowers to service their debt and resulted in rising loan losses in financial institutions, which started to mount during 1991. In the fall of 1991, it became clear that two of the six major banks, Första Sparbanken and Nordbanken, needed to be recapitalized to fulfill their capital requirements. Being the major owner of Nordbanken, the state injected additional capital into the bank, becoming the owner of 77 percent of the outstanding shares. It also issued a guarantee to the owners of Första Sparbanken for a loan that enabled the bank to fulfill its capital requirement.

In the spring of 1992, it was evident that Nordbanken's problems were considerably more serious than anticipated. Subsequently, the state bought all the remaining outstanding shares. In November 1992, the state injected SEK 10 billion to absorb losses related to provisions for probable loan losses and split Nordbanken into two entities by transferring most of the nonperforming loans to Securum, an AMC. Securum took over assets with a book value of SEK 67 billion, accounting for 4.4 percent of total banking assets. Assets transferred were mostly real estate related loans.

In September 1992, it became apparent that Gota Bank would not meet its capital adequacy requirements and the largest owner, Trygg Hansa, refused to provide the bank with additional funds. To calm markets, the government immediately announced a guarantee to Gota's creditors, which was later extended to all other banks (Berggren 1995). In the same month, Gota declared bankruptcy. In December 1992, the government acquired Gota Bank and issued a statement that the bank would be sold immediately. To facilitate the sale, as in the case of Nordbanken, the government split Gota Bank into two entities. Problem loans (most of which were real estate related) totaling SEK 43 billion, or 3 percent of total bank assets, were 
transferred to a subsidiary, Retrieva, which was to operate as an AMC, leaving the remaining entity to focus on normal banking business.

In December 1992, the government addressed the banking sector weakness more comprehensively and parliament passed the Bank Support Act authorizing the government to provide support flexibly in the form of loan guarantees, capital contributions and other appropriate measures. The Act also formally confirmed the government guarantee on all liabilities. To support the objectives of the Act, parliament set up a separate agency, the Bank Supervisory Authority, which had the authority to decide and manage bank support operation. During 1993, Nordbanken and Gota bank were merged, retaining the name Nordbanken, and becoming Sweden's fourth largest bank. The bank was operationally restructured and later sold to the private sector. Their respective AMCs-Securum and Retrieva-were merged in December 1995.

The main tasks of the AMCs were to maximize the remaining economic value of the loans transferred. During the first phase of their operations, the AMCs focused their activities on making decisions as to whether to have the debtors file for bankruptcy. In the majority of cases, the AMCs forced the debtors into bankruptcy, taking over the collateral (in most cases real estate property) and leaving the AMCs with the task of disposing of the real estate assets. For example, Securum was the owner of 2,500 properties with an estimated market value of SEK 15-20 billion, corresponding to 1-2 percent of all commercial real estate in Sweden (Englund 1999).

Securum sold its real estate assets through public offerings on the Stockholm stock exchange and private sales to companies and individuals. Most of the assets were sold in 1995 and 1996, when the real estate market had started to recover, but nevertheless, prices were still 
low by historical standards. Securum wrapped up operations much faster than originally envisaged and it was dissolved at the end of 1997.

As the above summary illustrates, Securum and Retrieva were not only successful in selling off their assets but also recovered substantial amounts from the disposal of their assets. Several factors contributed to their success. First and most importantly, the AMCs could rely not only on a strong judicial framework but also on an efficient judicial system, which allowed them to force most of their debtors into bankruptcy when their operations did not prove to be economically viable. The restructuring of the assets was also facilitated by the fact that most of the assets transferred were real estate-related assets. Real estate is easy to restructure, from a political standpoint, since restructuring does not tend to involve large lay-offs. In addition, the operations of the asset management operations also benefited from a skilled management team, strong governance mechanisms that insured the agency's independence, a limited amount of assets being transferred, and the provision of adequate funding (Klingebiel 2000).

\section{FOBAPROA in Mexico}

Starting in December 1994, Mexico suffered a systemic banking crisis, resulting from a banking system characterized by initial low levels of capital at the time of privatization, imprudent lending behavior, poor accounting practices and disclosure, weak regulatory and supervisory environment, and a weak legal and judicial framework in which debtors could default on their loans with little consequences (Mulas 2001). Connected lending was prevalent, as ownership dispersion requirements and rules separating banks and industrial firms were insufficient to avoid potential conflicts of interest (La Porta, Lopez-de-Silanes and Zamarripa 2003). 
In response to the financial meltdown towards the end of 1994, the government initiated several programs to support the banking system. Most of these programs were implemented through the Fund for the Protection of Bank Savings (FOBAPROA). One of these programs was the Loan Purchase and Recapitalization Program, which exchanged delinquent loans held by banks for government-issued bonds, to recapitalize banks that were undercapitalized.

FOBAPROA was originally created in 1990 as a deposit guarantee agency. FOBAPROA's mandate was broadened as a result of the banking crisis in 1996 beyond deposit insurance responsibilities to make it a bank rescue and intervention agency as well as an asset management company (Mackey 1999). We will focus on FOBAPROA in its function as an asset management company.

The FOBAPROA program failed at asset resolution. In late 1996, the Valuacion y Venta de Activos (VVA) was created as a supporting agent in the sale of FOBAPROA's assets. The VVA's activities were hindered by a number of obstacles. First, initially the government restricted financial institutions including the VVA from foreclosing on assets, because the selling bank remained the loan's legal owner. Second, the sheer size of impaired assets made it difficult to restructure debt and sell assets. At the peak of the program, FOBAPROA held more than 50 percent of the loans in the system. Third, the large scale and the type of assets transferred to FOBAPROA, i.e., corporate and politically-connected loans, were difficult to resolve for a government-agency susceptible to political pressure. The asset transfer was a non-transparent and repeated process that led to perceptions that some banks received more favorable treatment than others. Fourth, VVA's due diligence process was complex and lengthy, as the documentation of loans remained with the banks that administered or held the loans. Fifth, the 
responsibilities of the VVA and FOBAPROA were poorly defined, complicating the relationship between the two agencies (Mulas 2001).

In June 1997, the resolution activities of the VVA and FOBAPROA were merged into a single agency, the Direccion de Activos Corporativos (DAC), which became the sole agency overseeing corporate asset recovery. In its new function, DAC oversaw and coordinated the corporate debt resolution process of FOBAPROA's loan portfolio.

The sale of impaired assets was mainly through cash collections from auctions. However, DAC experienced problems in selling off assets for some of the same problems as faced by its predecessor. The absence of a secondary market made cash collections from auctions a difficult approach, politically-connected loans were difficult to resolve for a government-agency susceptible to political pressure, and substantial deficiencies in the bankruptcy and foreclosure code that limited DAC's ability to bring debtors to the negotiation table. Thus far, only 0.5 percent of the total assets transferred under the FOBAPROA program have been sold, with an average asset recovery rate of only 15 percent (IMF 2003).

The FOBAPROA program also did not have the desired result of reinvigorating the banking sector. Credit to the private sector fell considerably over the period 1995 to 1998 . As a share of GDP, private credit dropped from 39 percent at end-1994 to 19 percent at end-1998.

In early 1999, FOBAPROA was disbanded and the assets under its custody were transferred to a new deposit insurance agency, the Bank Savings Protection Institute (IPAB), with the authority to manage and dispose of closed banks' assets.

An additional failure of FOBAPROA was that funds were illegally transferred to Mexico's powerful elite. Under the opposition's pressure, the government decided to have an independent audit of the FOBAPROA program, including the loans under FOBAPROA's 
custody, to be carried out by a Canadian auditor, Michael Mackey. However, the strict bank secrecy laws in Mexico inhibited a thorough examination of the debts transferred to FOBAPROA and allegations of corruption. ${ }^{1}$

The FOBAPROA experience shows that corporate restructuring is hindered if there are inadequate bankruptcy laws and a lack of experienced judges and bankruptcy trustees to effectively manage bankruptcies. Above all, the Mexican experience shows that politicaleconomy factors can profoundly affect the success of government policies through the corruption of the recapitalization process. Recapitalization and asset resolution programs per se do not encourage a restart of lending, especially in a country where imprudent lending behavior and politically-connected lending are widespread.

\section{Asset Management Companies in Indonesia and Korea}

While it is beyond our scope to review other countries' experiences with AMCs in similar detail, it is fair to say that the failures in Mexico were representative of many countries' experiences, documented elsewhere. Here we briefly compare and contrast the experiences of Indonesia and Korea after the Asian crises. For reviews of these crises and resolution strategies, see World Bank (1999), and Scott (2002) for Korea, and Lindgren et al. (1999), IMF (2000), and Enoch et al. (2001) for Indonesia.

As a response to the financial crisis that erupted in Indonesia in the wake of the floating of the Thai bhat in 1997, the Indonesian government set up the Indonesian Bank Restructuring Agency (IBRA) with a wide set of responsibilities. Those included the restructuring of banks that were transferred to it, the recovery and restructuring of bank assets (including both physical

\footnotetext{
${ }^{1}$ Mackey (1999) reports that about $\$ 7.3$ billion of the loans (or more than 10 percent of total loans) transferred to FOBAPROA did not meet the criteria established for inclusion in the Loan Purchase and Recapitalization Program, and that just over $\$ 600,000$ of those loans was of illegal origin.
} 
assets and loans), and the recovery of state funds formerly disbursed to the banking sector (Lindgren et al. 1999).

On February 14, 1998, IBRA took over the surveillance of 54 banks, including 4 state banks and 50 private and regional development banks that had borrowed from Bank Indonesia more than 200 percent of their capital and had a capital adequacy ratio below 5 percent. They represented $36.7 \%$ of total system assets. The majority of the non-performing loans were transferred from the state banks. Seven of the 54 intervened banks were the largest borrowers from Bank Indonesia, accounting together for more than 75 percent of the total Bank Indonesia liquidity support.

Loans were transferred at book value, which created incentives for IBRA to hold, rather than dispose of, the assets to avoid recognition of the loss. IBRA's strategy toward debt restructuring was to focus on the largest debtors, while outsourcing or selling small- and medium-sized loans. The smaller retail and SME loans were sold through open auctions, while medium-sized commercial loans were outsourced in batches to servicing agents through a competitive bidding process. As for the largest corporate debtors, the approach focused on restructuring the loans of the cooperative debtors, taking legal action against non-cooperative debtors, and selling restructured loans through a competitive bidding system. Later, there was a shift towards direct loan sales at discounts (IMF 2000 and IMF 2001b). IBRA's success was rather mixed and the loan disposal rate only started to improve once the agency shifted to selling loans at a steep discount. Similar to Mexico, the agencies' activities were impeded by a weak judicial framework and weak enforcement mechanisms, the type of assets transferred (which were mostly corporate loans from state banks), and the large amount of assets transferred (as IBRA controlled over a third of total system assets at one point in time). 
In reaction to the financial crisis that erupted in Korea toward the end of 1997, the Korean government established an asset management company called Korean Asset Management Corporation (KAMCO) to improve banks' condition and accelerate debt resolution. During 1997 and 1998, KAMCO acquired thousands of individual assets, mainly operating and closed factories and commercial real estate. Total loans acquired amounted to KRW110.1 trillion, with NPLs of KRW39.8 trillion. These loans represented 14.7 percent of bank loans. Assets were initially acquired at above-market prices, but eventually at approximate market prices. On average, the transfer price had a $64 \%$ discount from face value.

Despite a slow start, unlike FOBAPROA KAMCO's disposition was rapid. Within roughly two years, KAMCO had resolved KRW64.6 trillion of NPLs, which represented 60\% of its total acquisitions, and had recovered KRW30.3 trillion, which represents $76 \%$ of the total amount spent to purchase the NPLs. More than 70\% of the remaining KRW45.5 trillion loans are related to Daewoo and are expected to require more time-consuming methods for liquidation. The reasons for KAMCO's relative success versus FOBAPROA and IBRA can be summarized as follows: (1) except in the case of Daewoo, KAMCO played a smaller role in corporate restructuring (Scott 2002); except for assets associated with the bankruptcy of Daewoo company, the assets transferred to the agency were real estate assets that were relatively easy to liquidate; (2) the Korean judicial framework offers better protection for creditors and better enforcement capacity than that of Mexico in the mid-1990s, and (3) the real estate assets transferred to KAMCO were easier to liquidate because they were less subject to political interference. 


\section{Lessons from the Case Studies}

In theory, AMCs seem to offer tempting prospects for avoiding many of the shortcomings of market-based solutions. Potential advantages include: (i) economies of scale in administering workouts (since workouts require specialized, and often scarce, skills) and in forming and selling portfolios of assets, (ii) benefits from the granting of special powers to the government agency to expedite loan resolution in an environment of weak market incentives and legal institutions, and (iii) the interposing of a disinterested third party between bankers and clients, which might break "crony capitalist" connections that otherwise impede efficient transfers of assets from powerful enterprises. The latter may seem particularly beneficial in emerging markets, where ownership concentration and connections between industrial conglomerates and banks are often very close.

Sweden's AMCs provide examples of some of these potential advantages, but other countries found it difficult to realize those advantages. First, government agents may lack the information and skills of (more highly compensated and incentivized) private market participants. Second, government agencies do not operate in a vacuum; they, too, are creatures of the societies that create them, and government agents must negotiate, rather than dictate, solutions, just as private market participants must do. In negotiations with government agencies and private participants alike, the strength of one's position depends on one's "threat point" (the ability to credibly threaten adverse consequences to one's bargaining opponent, if agreement is not reached).

In environments where legal, regulatory, and political institutions are weak, the threat point of government officials in restructuring negotiations is substantially curtailed. Uncooperative firms and banks may have little incentive to participate in government initiatives or to settle on reasonable prices if failing to do so has no adverse consequence for them. In an 
environment where powerful business leaders do not fear legal or regulatory consequences, and where appeal can be made to corrupt politicians or bureaucrats for protection, even a well meaning and competent AMC negotiator has little chance of being effective. Thus, the notion that AMCs avoid the dependence on the quality of the legal and regulatory environment that undermines market-based solutions is mistaken because it fails to take into account the effects of weak institutional environments on the ability of AMCs to achieve their objectives (Klingebiel 2000). Third, AMC officials are subject to special incentive problems (corruption and political pressure to favor certain borrowers or to avoid layoffs at large firms), which can make them less willing to push for effective solutions. AMCs tend to be least effective when the transfer of assets amounts to a large share of total system assets, which tends to increase the politicization of the workout process. The problems of poorly structured incentives and large program size tend to magnify each other. Mexico's FOBAPROA was made increasingly unsuccessful as the lack of credible loss sharing on the downside encouraged over-participation.

Because AMCs can be a means of transferring enormous subsidies to certain banks, firms and individuals, they often create enormous costs in the form of moral hazard. Whether loan losses are recognized by banks after the establishment of an AMC depends on the transfer price of assets determined by the managers of the AMC. Bank loan losses are not recognized if assets are transferred at a price above market value, resulting in a back-door bank recapitalization. An $\mathrm{AMC}$ also does not impose losses on corporate borrowers, and therefore, does not set incentives to improve borrower behavior in the future. In fact, it may offer special arrangements to benefit certain borrowers, or avoid pressuring certain debtors to sell, or effectively pass through assistance to cronies through overpriced purchases of loans to connected banks. A related point 
is that corporate loans, particularly of large conglomerates, are the hardest type of loans to resolve through AMCs because they are most prone to political influence peddling.

\subsection{Government-Assisted Sale of Financial Institutions to Foreign Banks}

This approach is a government-assisted sale of financial institutions to strategic (typically foreign) investors. Assistance usually takes the form of government sharing of loan losses to some extent, and also the relaxation of preexisting limits on the activities of foreign banks. The objective of such a sale is to improve the efficiency and the capital base of financial institutions in the country. This resolution mechanism is a government-based and centralized approach to bank restructuring. Since actual corporate restructuring is left to the market, a governmentassisted sale of financial institutions is a decentralized approach to corporate restructuring.

To what extent can the sale of distressed domestic banks to foreign entrants substitute for preserving domestic banking franchises? Foreign bank entry is a large potential source of new capital, and one that is less likely to be diverted to value-destroying investments. And foreign entrants into distressed banking systems tend to enjoy a relatively low cost of capital, because they have not suffered capital destroying loan losses, and because they are better able to raise new capital because the absence of loan losses also means that markets will impose lower adverse-selection discounts on any new bank capital offerings (Calomiris and Wilson 2003).

While there is evidence that foreign entry enhances the efficiency and stability of banking systems (Demirguc-Kunt, Levine, and Min 1998), it can take time for foreign entrants to establish information about borrowers and familiarity with local legal and institutional arrangements. Calomiris and Carey (1994) find that foreign bank entrants into the United States during the U.S. bank "capital crunch" of the 1980 s tended to lend disproportionately to lower- 
risk borrowers, tended to purchase rather than originate loans, and tended to act as syndicate participants rather than lead managers. Furthermore, despite their conservative loan purchases and originations, foreign banks tended to suffer worse loan losses in the U.S. than domestic banks in the early 1990s, which further suggests an information cost disadvantage. Although relaxing barriers to foreign entry is clearly a crucial part of resolving a credit crunch and reforming long-term lending practices, foreign bank lending may not be a perfect substitute for domestic bank lending in the short run. At the same time, if foreign entrants can acquire existing franchises and human capital along with their acquisition of assets and real estate, they could make immediate inroads into lending to firms of all kinds.

Another limitation of foreign banking may be its reliability as a source of continuing future credit. Some observers have voiced a concern that foreign banks will be more likely to flee in the future if economic conditions deteriorate. In theory, that could occur because global banks have the option to shift capital among the countries in which they operate, and consequently may reduce their allocation of credit more in reaction to adverse changes in the economy than a domestic bank would.

To gain perspectives into the benefits and potential limitations of foreign bank entry we consider two important recent cases of foreign entry in emerging markets: Argentina and Mexico during the 1990s.

\section{Foreign Entry into Argentine Banking}

Argentina, like much of Latin America, had suffered high inflation, economic decline, financial distress and sovereign default during the 1980s. It embarked on a major financial and economic liberalization program at the beginning of the 1990s. The program sought to bring an end to 
hyperinflation (through a credible commitment to dollar convertibility of the peso), privatize state-owned enterprises (including public banks), deregulate the financial system, abolish deposit insurance, and deregulate foreign capital flows. All of these elements were attractive to foreign banks, particularly given the backwardness of the Argentine banking system. The potential for growth of deposits and loans was enormous and the operating inefficiency of the domestic banks was apparent in both large quantities of bad loans and high physical costs of operations.

Foreign banks were permitted to participate fully in the recovery of the financial sector from the beginning, and they became important players from an early date. Total credit to the private sector rose from 10\% of GDP in 1990 to $19 \%$ in 1994. As early as 1994, foreign lenders accounted for $25.4 \%$ of personal loans, $10.3 \%$ of mortgages, and $19 \%$ of commercial loans (Dages, Goldberg, and Kinney 2000).

When the spillover effects of the Mexican tequila crisis hit Argentina in 1995, foreign banks played a growing role in credit markets. Foreign banks had lower risk loan portfolios, and hence lower losses during the crisis, and their sources of capital were relatively immune to the local shock. These differences put them in a position to grow their lending and to expand their franchises through the acquisition of weak institutions. Had the tequila crisis been perceived as undermining the long-run desirability of operating in Argentina, the reaction would have been different, but in the event, foreigners viewed the adverse shock as a short-term problem, and therefore, a window of opportunity to build for the future.

By 1999, the foreign-owned bank share in personal lending had grown to $45.8 \%$, the share of mortgage lending stood at $31.9 \%$, and the commercial lending share was $53.2 \%$ (Dages, Goldberg, and Kinney 2000). The number and countries of origin of foreign bank entrants were also large and diverse. Major acquisition deals involved new foreign entrants such as Banco 
Santander, Banco Bilbao Vizcaya, HSBC, Bank of Nova Scotia, Bank of Austria, Caisse Nationale de Credit Agricole, Chile's Abinsa and O'Higgins banks, and Brazil's Banco Itau, which joined the already established foreign banks (Citibank, Bank of Boston, ABN Amro, and Lloyds). Probit analysis of foreign banks' acquisition behavior (Cull 1998) indicates that foreign banks looked for large acquirees as a means to gain market share. The tolerance for weak targets of acquisition, and the desire to build market share quickly made foreign entry particularly valuable.

Foreign bank entry initially was concentrated in the capital city, where foreign banks lent $88.5 \%$ of their loan portfolio in 1997 , compared to only $40.8 \%$ for private domestic banks, but in provinces that privatized their public banks, foreign bank credit grew rapidly after 1995 (World Bank 1998). Foreign banks also initially supplied credit to sectors that were relatively neglected by domestic banks. In particular, foreign banks were much more focused on financing manufacturing sector growth; $29.8 \%$ of their loans went to that sector, in contrast to only $13.1 \%$ for private domestic banks. Foreign banks maintained comparable or slightly better loan portfolio quality than other private banks, indicating a comparable or slightly lower risk loan clientele. For the period 1997-1998, on average, non-performing loans as a fraction of total loans were $9.7 \%$ for foreign retail banks and $8.0 \%$ for foreign wholesale banks. Private domestic retail banks had average non-performing loan (NPL) ratios comparable to foreign banks (9\%), but higher median NPL ratios. The average NPL ratio for private domestic wholesale banks was 19.4\% (Calomiris and Powell 2001). Clearly, foreign bank entry was providing a large, increasingly diverse, and growing supply of credit to the Argentine economy.

The presence of active foreign bank acquirers with available capital also spurred the privatization of many distressed public banks, which otherwise would have been difficult to 
resolve. From 1995 to 1999,15 banks were privatized. Privatization was also encouraged by the existence of a special fund, subsidized by the World Bank and other multilateral agencies, to encourage provinces to privatize their public banks (Calomiris and Powell 2001).

The entry of foreign banks contributed to the stability of the economy in the late 1990s, too, both because of their immediate effect in supplying credit in response to the tequila shock, and because of the long-run stabilizing effect of their presence. From the fourth quarter of 1994 to the fourth quarter of 1995 (the window of the tequila crisis) foreign bank lending grew at a $12 \%$ annual rate, which was higher than the growth rate of private domestic banks. From the end of 1995 through the end of 1999, foreign banks' loan growth was greater than 22\% per year, which was also higher than domestic private banks' loan growth (Dages, Goldberg, and Kinney 2000).

The long-run stabilizing effect of foreign entry largely operated through the leeway that foreign bank entry and robust loan growth gave regulators to strengthen and enforce the regulation and supervision of the banking sector. Without the robust growth of foreign lending, regulatory discipline would have required the scaling back of lending, which would have been more difficult politically.

Although foreign bank entrants had been patient acquirers of long-term assets and relationships throughout the 1990 s, government policy after 2000 has produced a general retreat of foreign investors from Argentina in which the banks have participated. The Argentine fiscal crisis created costs for the banks, first in the form of loan losses produced by the recession, then in the form of losses due to government pressures on banks to purchase government securities and subsequent sovereign default, and later by "asymmetric pesification" of bank assets and liabilities. Beginning in late 2001 some foreign banks began to retreat from their distressed 
operations. Scotiabank refused to pump additional capital into its bank and instead abandoned Scotiabank Quilmes, writing off C\$540 million. Credit Agricole abandoned its subsidiaries in 2002.

\section{Foreign Entry into Mexican Banking}

Mexico's history of foreign bank entry shares some features with Argentina's, but there are important differences. The Mexican government was far more reluctant to admit foreign entrants, and only established unfettered entry rules after 1997, fully two years after the tequila crisis. And because new foreign bank entrants came into the country after the collapse of the domestic financial system, and before a full resolution of the problem of non-payment of debt, the shortterm effects of foreign entry on loan supply understandably have not been as dramatic. Nevertheless, the effects of foreign bank entry on loan supply and on the improvement in the regulatory and supervisory regime have been significant.

The Mexican banking sector was re-privatized in the early 1990s after a decade-long experiment with state-controlled banking. The growth of domestic credit was phenomenal. From the middle of 1989 to the end of 1991, bank credit doubled. From the end of 1991 to the end of 1994, bank credit doubled again.

In a sense, Mexican privatization was doomed from the outset. Many of the privatized banks had massive quantities of low-quality or non-performing loans at the time of their privatization, and privatization did not entail much in the way of paid in capital contributions by purchasers. Evergreening of bad loans was a firmly established practice even before the tequila crisis, a practice supported by dishonest accounting rules. This practice served the interests of the bank owners, since it helped them to claim to be in compliance with regulatory standards and 
thus to avoid the costs of recapitalizing the banks. Like the U.S. savings and loan institutions, Mexican banks were betting with someone else's money. Most of that betting took the form of risky peso-denominated lending, but Garber (1998) argues that banks also illegally used offshore derivatives positions to speculate against peso depreciation. And much of the bad lending was to connected enterprises. As is often the case in emerging markets, banks that receive subsidies from the government safety net often channel those to related firms through loans at concessional interest rates. Although Mexican law prohibited industrial firms from owning banks, it did not forbid the owners of industrial firms from owning banks.

So long as the dream of never ending growth panned out, all would be well. Loans would be repaid and bank capital would accumulate. But that was not to be. Instead, the recession that began at the end of 1993 turned into the fiscal and monetary policy problems, and political chaos, of 1994. The government's policy - which consisted of a lack of fiscal reform, the growth of off-balance sheet fiscal costs, and unsustainable sterilization of reserve outflows - ultimately produced the currency collapse of December 1994, which was followed by massive private sector defaults, which made it unmistakably clear that the banking system was deeply insolvent.

The supply of credit within the banking sector slowed to a trickle after the crisis. Even forbearance was not enough to restart the credit process, for two reasons. First, the legal foundations of creditors' rights were in shambles. With the exception of profitable exporting firms (who had both the means and incentive to pay their debts, and who were less dependent on the Mexican legal system to enforce their contracts) there were few borrowers that could credibly commit to repay any new credit that was granted. Second, forbearance was no longer able to fully protect deeply insolvent banks from the consequences of their insolvency. Deeply insolvent banks had trouble keeping depositors, despite 100\% deposit insurance. That fact 
reflected the growing size of the cost of the banking sector losses to taxpayers, which led people to question the government's process to bear all those losses.

Consider the difference between the interest paid on deposits by Bank Serfin (the weakest of the big domestic banks) and by Banamex (the strongest) a year after the tequila crisis. As of 1996, the average total cost of funds for Banamex was $17.37 \%$, and for Serfin, $28.93 \%$. As is often the case in emerging markets - even in the presence of some form of government insurance - the risk that insurance will not fully cover enormous losses can produce a large default risk premium. Also, some of the cost of funds difference reflected the fact that business depositors (the main holders of sight deposits) preferred to maintain relationships with banks that were likely to be survivors. Sight deposits represented only $12 \%$ of Serfin's funding sources, while they comprised $24 \%$ of Banamex's deposits. Bancomer, which was less well off than Banamex, but much better off than Serfin, had a $21.89 \%$ cost of funds and relied on sight deposits for $21 \%$ of its financing (Calomiris 1998).

In the post-tequila environment, domestic lending was not a growth area (due to the distress of borrowers and the lack of incentive for borrowers to repay debts). Banks that were relatively well off (e.g., Banamex, and to a lesser extent, Bancomer) focused on expanding their brick and mortar franchises to generate cheap deposits, and invested the proceeds in government securities. From 1995 to 1996, Banamex's branches grew from 716 to 912 and Bancomer grew from 885 branches to 1,260 . Serfin meantime grew slightly from 564 to 578 branches. Asset growth differences were similar: Banamex grew assets by $23 \%$ during 1996, and Bancomer grew assets $17 \%$, while Serfin grew by $12 \%$.

Interestingly, despite the limited opportunities for loan growth, the post-1995 period ushered in a new era of expansion in foreign bank presence in Mexico, but that entry did not 
occur immediately after the tequila crisis. At the time of the crisis, there were only two significant foreign banking franchises operating in Mexico, Citibank and Santander, and of the two, only Citibank (which had been granted an exemption to the ban on foreign control of banks, owing to its longstanding presence in Mexico, dating to the 1920s) was an active lender at the time. Citibank was still a small player, accounting for under $1 \%$ of banking system loans, and operating only six offices in Mexico City. The initiation of NAFTA in 1994 had begun a gradual and partial process of easing restrictions on foreign entry. Under NAFTA, no U.S. or Canadian bank could exceed $1.5 \%$ of the total domestic banking market through 1999, and the sum of all foreign banks shares could not exceed $8 \%$ in 1994 or $15 \%$ in 1999. In 2000 , both the individual and aggregate limits were set to expire, except that foreign acquisitions would still be limited to prohibit any foreign acquirer from gaining more than $4 \%$ market share per year via acquisition. And for non-NAFTA foreigners, they were not permitted to own more than a $30 \%$ share in any financial group or commercial bank. These restrictions effectively meant that, as of 1994, no foreign bank could ever hope to acquire one of the largest domestic banks.

The crisis presented enormous growth opportunities for the two foreign banks that were in Mexico. Santander (which was operating seven branches of its Puerto Rican bank in Mexico under a special arrangement) had just begun operations in Mexico and was holding primarily Tesobonos (dollar-indexed assets) at the time of the crisis. It had received permission in advance of the crisis to hedge its exposures in dollars rather than in pesos. When the peso depreciated, its capital position soared and it rapidly became a significant lender to industrial firms. Because of its access to cheap capital and its ability to hedge dollar exposures abroad, it was able to grant three-year dollar-denominated loans to top-tier firms at a time when domestic banks were not offering such attractive terms. 
Prior to the crisis, Citicorp had been developing an aggressive strategy for growing its Mexican business. Citicorp had preexisting relationships with many top Mexican firms, the most notable of which was Cemex, the largest company in Mexico and the fourth largest cement producer in the world. Like Santander, Citicorp benefited from the relative weakness of domestic banks after the crisis, particularly to serve the needs of large, high-quality firms for dollar loans and international payments services. Citicorp experienced a $250 \%$ rise in its Mexican liabilities within six months of the crisis.

The "demonstration effect" of showing clear advantages to the Mexican government and corporations from the presence of Santander and Citibank encouraged rules on foreign entry to be relaxed further. In 1996, after several months of negotiations and due diligence, Santander agreed to take control of Grupo Financiero Invermexico (GFInver) through the purchase of a $75 \%$ stake. This acquisition marked the first time that an international institution had acquired control of one of the 18 large Mexican banks privatized in the early 1990s. In 1996, Scotiabank (which had purchased an $8.5 \%$ interest in Inverlat in 1993) was permitted to purchase a controlling interest in that bank. BBVA was allowed to acquire Banco Mercantil Probursa in 1995 and Banca Cremi and Banco Oriente in 1996.

In 1997, control over the lower house of government changed hands, partly because political accusations of corruption and favoritism were bolstering the opposition. The FOBAPROA approach to asset resolution was in shambles (see section 2.5). In 1998, the Mexican Congress approved foreign ownership of up to $100 \%$ in Mexican banks. In 1998, Citibank became the first U.S. lender to take control of a troubled Mexican bank, buying Banca Confia from the Mexican government for $\$ 195$ million. 
By 1998 , foreign banks had come to hold $11.1 \%$ of consumer loans, $6.4 \%$ of mortgages, and $19.7 \%$ of commercial loans (Dages, Goldberg, and Kinney 2000), a remarkable increase from essentially zero in 1995. Dages, Goldberg, and Kinney (2000) find that foreign banks behaved similarly to healthy domestic banks in terms of loan growth. The key to foreign banks' abilities to operate in Mexico, and to help resolve the distress of the banking system, was their access to new capital.

In 2000, a major test of the regulatory authorities came, when the previously announced takeover of Bancomer by BBVA was challenged by a competing offer by Banamex, made on Mexican Independence Day. A combination of Banamex and Bancomer would have produced the best client list in Mexico, and an entity that would likely have benefited from becoming too important to be allowed to fail. From the standpoint of efficiency, competition, the avoidance of moral hazard, increasing access to capital, and putting an end to crony capitalism, the acquisition by BBVA was clearly superior, but Banamex was hoping that nationalism would help it win the day. In the event, the Mexican regulators and politicians did not blink, and BBVA was able to consummate the deal, leaving it with the largest bank franchise in Mexico.

Part of the reason for that landmark decision was that the entry of foreign banking in Mexico had already removed much of the pressure on the government to prop up its domestic banks. In that sense, foreign entry in Mexico was a "virtuous circle," where entry reinforced further entry by undermining the grip that the domestic banks had on the economy and the political and regulatory system. Foreign bank entry gave well-intentioned regulators and politicians an option other than crony capitalism, and they chose it. In addition to the acquisition of Bancomer, in 2000, Santander acquired Serfin, and in 2001, Citibank acquired Banamex, which no longer felt it could compete without the access to capital of a foreign parent institution. 
In 2002 HSBC bought all the shares of Bital, including those that had been purchased by ING and Santander previously, and added $\$ 800$ million to Bital's capital.

Despite the rapid transformation and recapitalization of the Mexican banking system brought about by foreign entry, bank lending has been slow to recover, owing to the continuing problem of nonpayment, which has deeper legal roots in the problems of the bankruptcy law and court, and in other creditor rights laws and courts. The Mexican government attempted a total reform of the bankruptcy law and courts, and the law for collateralization, in 1999. Still, the laws have been challenged and legal risks have remained high.

\section{Lessons from the Case Studies}

The experiences of Argentina and Mexico cast a very favorable light on the role of foreign banks in resolving domestic bank distress. Government-assisted sales of banks to foreigners can be a cost-effective way to restore bank capital, and proper lending incentives. Foreign banks' access to capital and willingness to invest in long-term relationships allow them to compete very effectively for loans, and provide an important offset to the shrinkage in lending that occurs after the collapse of domestic banks. Unlike the experience of the U.S. in the 1980s (Calomiris and Carey 1994), in Argentina and Mexico foreign banks were able to enter all niches of the banking market successfully, perhaps because they did so more via acquisition, and because existing domestic banks were in distress. Also, contrary to the fear of foreign entry critics, banks did not flee from either Mexico or Argentina during the major crisis of 1995, but rather redoubled their investments, seeing the crises as windows of opportunity to expand. Several foreign banks did leave Argentina, however, in response to the 2001 crisis and resulting policy-induced losses. 
Despite these advantages, which were reaped in both countries, Mexican bank credit has still been slow to grow, owing to institutional problems in credit markets that are beyond the banks' control. Bank capital, by itself, does not restore borrowers' financial health, nor bolster creditors' rights enough to make arms-length lending profitable. This case illustrates that the advantages to foreign entry can only be fully reaped (especially in the area of SME lending) if legal institutions permit it. Indeed, some foreign entrants into Mexico have been disappointed by the slow pace of reform in the legal system. If these problems had been foreseen, it is possible that foreign entrants would have been more reluctant to commit capital to Mexico in the 1990s.

One important lesson that comes from both the Argentine and Mexican cases is that the presence of foreign banks helps to improve the regulatory structure of the countries that they enter. Not only do foreign banks directly impose competitive pressure on other banks; they increase competition indirectly by making it more likely that bank supervisors and regulators will decide to end forbearance, enforce bank regulations, and encourage further competition as the means for resolving the system's problems. In other words, the political economy of bank regulation is endogenous to the presence of foreign banks in a desirable way.

\subsection{Government-Assisted Recapitalization}

This resolution measure involves the recapitalization of financial institutions with government

assistance. The objective is to improve the capital base of financial institutions. Governmentassisted recapitalization takes a decentralized corporate restructuring approach, as actual corporate restructuring is left to the market. Whether government-assisted recapitalization is a government-based or market-based approach to bank restructuring depends on how governmentassistance is structured. 
As examples of government-assisted recapitalization we consider the RFC preferred stock program of the United States that began in March 1933, the recapitalization program of Japan beginning in 1998, and the restructuring program of Thailand that began in October 1997.

\section{The Reconstruction Finance Corporation (RFC) in the United States}

Measured by bank failure rates, depositor loss rates, or the extent of bank credit contraction, the Great Depression was, and remains, the largest and most persistent shock suffered by the U.S. banking system since (at least) the 1830s. The combination of the high failure rate and high depositor loss rate during the Depression produced a loss rate on total deposits in excess of $2 \%$ in 1933. Although these losses were large relative to previous U.S. experience, they are quite small relative to the experiences of many countries today.

Despite the "low" failure rates of banks in the 1930s compared to emerging market economies today, the consequences of bank distress for credit supply were large and protracted, as noted by Fisher (1933), Bernanke (1983), and Calomiris and Mason (2003c). Banks with high asset risk and low capital posed a large risk of default to depositors, and depositors withdrew funds as the risk of default rose. The consequence of market discipline was that banks faced strong incentives to contract credit supply before they failed. Market discipline resulted from the fact that the government safety net for banks was quite limited. Assistance during the 1930s included loans from the Fed, loans and (after March 1933) preferred stock purchases from the RFC, and federal deposit insurance on small deposits beginning in 1934. Deposit insurance was limited to small deposits and banks that were insolvent in 1933 were not permitted to qualify for deposit insurance in 1934. And, as we shall see, loans and preferred stock were supplied in a way that limited the potential abuse of such assistance. 
Although market discipline was present in the 1930s, and insolvent banks were allowed to fail, the removal of bank assets from bankers' control did not imply the speedy resolution of borrowers' distress. Non-performing loans of insolvent banks were not liquidated quickly during the Depression. As in many crisis countries today, as the stock of failed banks' loans accumulated, the speed of loan resolution slowed. This loan resolution backlog effect is analyzed by Anari, Kolari, and Mason (2002). They find that this measure of financial sector distress is a better forecaster of economic activity, and a better explanatory variable for the persistence of output decline during the Depression, than previously used measures of financial sector distress. The important implication of this research is that system-wide bank failures pose special costs to society, not just because of the loss of lending capacity by banks that have lost capital, but additionally, because of the effects of bank asset liquidation on consumer liquidity and the accentuated liquidity premium in property markets. It follows that an additional benefit of assistance to banks, and counter-cyclical macroeconomic policy, during a Depression is their positive effect on the liquidity of bank assets and liabilities. Clearly, the major motivations in the minds of the founders of the RFC for helping some banks remain in existence included both the preservation of suppliers of new credit and the desire to stem the tide of bank asset liquidations and their depressive effect on asset prices.

Initially, the RFC operated under the same conservative lending rules as the Fed. After the ouster of its Chairman in July 1932, RFC collateral standards were relaxed. Lending to banks and other firms grew thereafter. Beginning in March 1933, the RFC's newly created preferred stock purchase program dominated its assistance to banks.

Part of the shift to preferred stock reflected the widespread view that secured loans did not stabilize weak banks (James 1938). Secured loans represented a senior claim on bank assets 
relative to deposits, and thus effectively worsened the default risk faced by junior depositors. Olson (1977) writes that: "High collateral requirements forced [banks] to isolate their most liquid assets as security for RFC loans. In April 1932, for example, the RFC loaned the Reno National Bank over $\$ 1.1$ million, but in the process took as collateral over $\$ 3$ million of the bank's best securities. This in itself left the bank unable to meet any future emergency demands for funds by depositors.” In Olson's (1972) view, loans from “...the RFC helped only those basically sound enterprises which needed temporary liquidity." It was not a means of reducing default risk for a capital-impaired bank; thus, it provided little relief to banks from default risk-intolerant market discipline.

Preferred stock, in contrast, was junior to bank deposits, and was not secured by highquality bank assets. Thus, it offered a means of lowering deposit default risk and thus insulating risky banks from the threat of deposit withdrawal. By March 1934 the RFC had purchased preferred stock in nearly half the commercial banks in the United States. By June 1935, these RFC investments made up more than one-third of the outstanding capital of the banking system (Olson 1988).

Mason (1996, 2001) and Calomiris and Mason (2003a) examine the relative effectiveness of loans and preferred stock purchases by the RFC, after controlling for differences in the characteristics of banks receiving both kinds of assistance. According to these results, receiving a loan from the RFC actually raised the probability of bank failure, while receiving preferred stock assistance reduced the probability of failure.

Although this evidence indicates that preferred stock purchases were effective in insulating banks from deposit withdrawal, it is important to emphasize that the RFC preferred stock program was successful because it was neither too conservative nor too liberal with its 
assistance. The RFC would have made little difference if it had only targeted the lowest risk banks for its subsidies. That was not the case. But, at the same time, the RFC did not provide assistance to deeply insolvent banks, nor would its assistance have been a sufficient subsidy to bail out such banks. Moreover, the conditions attached to RFC preferred stock purchases served to limit bank risk transference to the RFC, which ensured that preferred stock issuers had incentives to limit risk. Thus capital-impaired (but not deeply insolvent) banks were offered limited protection from market discipline essentially on condition that they did not abuse such protection by transferring too much risk to the government.

How did RFC conditionality ensure this "happy medium" of controlled risk? First, it offered limited subsidies to banks, and avoided trying to save "basket cases". The RFC required banks to submit their regulatory examinations for RFC inspection, and banks that were judged as hopelessly insolvent were rejected. Further evidence of the selective nature of assistance is that dividend rates on RFC preferred stock were typically less than one percent below those earned in the marketplace, and were above market rates on short-term business loans. In part, the limited subsidy offered by the RFC reflected its independent corporate status. Its financial independence led its chief executive, Jesse Jones, to see a need to make the RFC profitable on a cash flow basis, and he proudly proclaimed that it never saw a year of negative profit under his direction. That constraint, obviously, also limited the potential size of the subsidy the RFC could offer. For this very limited subsidy to have made a difference for bank failure risk, recipients could not have been deeply insolvent.

Second, many restrictions on recipients of RFC assistance ensured that banks would not take advantage of RFC aid by increasing their default risk. The RFC was intended to protect banks from a dramatic decline in their capital, but not to encourage capital-impaired banks to 
imprudently expand their portfolio risk. Indeed, the RFC went to great pains to impose conditions that substituted for depositor discipline on bank risk taking. Those conditions included seniority of RFC dividends to all other stock dividends and voting rights that effectively gave the RFC the ability to direct institutions toward solvency and profitability and limit excessive risk. In many instances, the RFC used its control rights to replace bank officers and significantly alter business practices (Calomiris and Mason 2003a).

The RFC preserved its seniority of claim on bank earnings by limiting common stock dividend payments. Common stock dividends were strictly limited to a specified maximum and remaining earnings were devoted to a preferred stock retirement fund. Some firms avoided applying for RFC preferred stock purchases out of reluctance to submit themselves to RFC authority.

Finally, although there were numerous attempts by politicians to influence RFC decisions, Mason (1996) suggests that the budgetary structure of the RFC and its decentralized process of decision making insulated the RFC from political manipulation. Field offices were given a large degree of autonomy over valuation of collateral and other judgmental decisions, but were held accountable to the central office for having made errors that reduced RFC earnings (Delaney 1954).

Bank dividends fell dramatically from 1929 to 1934 . To what extent was this decline in dividends, and other measures to limit bank default risk, the result of RFC conditionality? Calomiris and Mason (2003a) find that receiving preferred stock assistance significantly increased banks' capital ratios and reduced their dividend payout. Their results confirm that banks that received preferred stock assistance were effectively constrained in the extent to which their stockholders could transfer risk to the RFC. 
RFC preferred stock assistance was a way to help banks smooth the adjustment process toward low default risk. It insulated banks from the threat of sudden deposit withdrawal by reducing deposit default risk, but substituted RFC discipline for market discipline to ensure that banks adopted prudent long-run risk management and capital accumulation policies.

The banking crisis in the United States during the Great Depression provides a useful historical example of how policy makers can balance the opposing needs of protecting banks and maintaining market discipline over banks. The authorities managed to mitigate the loss of capital in the banking system and its effects on credit supply, while retaining market forces that continued to reward relatively prudent banks.

\section{Bank Recapitalization in Japan}

When in early 1998 it became apparent that the loan loss write-off program failed to provide adequate incentives for rational disposal of bad loans (see the case study of this program in section 2.2), and the financial condition of Japan's financial institutions continued to deteriorate, the government decided to provide direct financial assistance to ailing financial institutions in the form of loans and debt purchases, and subsequently in the form of preferred stock purchases. ${ }^{2}$ Two major injections of public funds occurred in March 1998 and March 1999, amounting to Y 1,726 billion respectively Y 7,459 billion (Calomiris and Mason 2003a).

While the recapitalization program had the expected effect of increasing the capital of Japanese banks, the program failed to set incentives for prudent behavior in the future because it did not make recapitalizations conditional upon the quality of the bank or the risk management and recapitalization behavior of the bank. Unlike the experience with the RFC in the U.S. in the

\footnotetext{
${ }^{2}$ Up to late 1997, the government had relied on the so-called convoy system in which strong banks were called upon to support weaker banks. The stronger banks were given tax incentives to do so.
} 
1930s, in Japan virtually every bank of any significant size received preferred stock assistance.

The government did not try to target assistance selectively or to require banks to find private sources of capital alongside government contributions. And the government was even willing to purchase preferred stock in banks as they continued to pay out large amounts of common stock dividends. Calomiris and Mason (2003a) provide suggestive evidence that the weakest Japanese banks were among the earliest and largest recipients of preferred stock purchases.

It should therefore not be surprising that the effect of the recapitalization program was not lasting. Although the capital adequacy ratio of local banks increased from $6.6 \%$ in 1998 to $10.0 \%$ in 2000 , by the end of the year 2002 the capital adequacy of this group of banks had again deteriorated to $8.4 \%$ (Bank of Japan 2003). Japan's recapitalization program also failed to foster corporate restructuring or to re-start bank lending. The ratio of private credit to GDP deteriorated from $203 \%$ in 1996 to $192 \%$ in 2000 , and further to $176 \%$ in 2002 . The lack of credible commitment by the government to end deflationary monetary policy and engage in bank and corporate restructuring set the stage for continuing mismanagement of risk and deterioration of banks' balance sheets as banks continued to postpone asset liquidation in the hope that they could avoid regulatory discipline and receive additional assistance from the government. Although capital injections have reduced since 1999, the end of this sad story has yet to come.

\section{Bank Recapitalization in Thailand}

The Thai case shows a number of similarities with the Japanese case, illustrating that a marketbased approach to bank restructuring yields limited results in a weak institutional environment. In Thailand, banks' liabilities were credibly backed by a government guarantee, the government engaged in regulatory forbearance, there was poor supervisory enforcement, the judicial 
framework for enforcing contracts and bankruptcy laws was weak, and the judiciary was inefficient. These institutional weaknesses undermined the effectiveness of bank recapitalization efforts.

In Thailand, the financial crisis came to light in July 1997, when an ailing financial sector, an export slowdown, and large increases in central bank credit to weak financial institutions triggered a run on the baht. As in the Japanese case, the Thai government was slow to address the financial system distress. It attempted to keep financial institutions afloat by injecting liquidity and engaging in regulatory forbearance and issued an unlimited guarantee on banks' liabilities as a delayed and partial response led to financial turbulence and runs on financial institutions.

On August 14, 1998, the Ministry of Finance and the Bank of Thailand announced a three-pronged plan to enhance the financial sector restructuring program. First, already relatively weak capital adequacy requirements were eased by lowering Tier-1 requirements for banks from $6 \%$ to $4.25 \%$ and the Tier- 2 requirement was increased from $2.5 \%$ to $4.25 \%$. Second, the government earmarked 300 billion baht for two capital support schemes: the Tier-1 and Tier-2 schemes (World Bank 2000).

Commercial banks were reluctant to take advantage of the government sponsored recapitalization schemes - particularly the Tier-1 scheme. Under the Tier-1 scheme, in return for official money, a bank had to first meet strict loan loss provisioning rules, requiring a corresponding write down of capital. The scheme would have resulted in a severe dilution of ownership, which could have resulted in a change of management. Instead, large banks used innovative ways to raise new capital to avoid participation in the government scheme and the potential dilution of ownership that came with it. Bangkok Bank, Thai Farmers Bank, Bank of 
Ayudhya and Thai Military Bank raised capital in the amount of around 113 billion baht, partly in the form of Capital Augmented Preferred Securities (CAPS) and Stapled Limited Interest Preferred Securities (SLIPS), preventing a dilution effect to existing shareholders.

Yet, this form of capital proved costly, as it increased banks' overall funding costs. Even in the case where a bank booked no earnings in one year and hence paid no dividends for preferred shares-cum-subordinated debentures, investors received about 11 percent from the investment, six percentage points above current deposit rates. This, in combination with the carrying cost for the large amount of NPLs, not only constrained banks' capacity to recapitalize on a flow basis, as was the intension under the government's regulatory forbearance scheme, it also hampered corporate restructuring as capital constrained banks' had little incentive to write down their assets and engage in meaningful corporate restructuring (World Bank 2000). The combination of regulatory policies provided a strong incentive to continue delaying recognition of losses and not participate in the government program, and made matters worse by decreasing the current cash flow of the banks. The result was a lack of progress in recapitalizing banks, recognizing losses, or restructuring corporate debt.

As late as 2002, the non-performing loan ratio stood at 39 percent of total system loans and Thai banks classified 16 percent of their total assets as non-performing. In addition, private credit continued to decline. In 2002, private credit to GDP was 103 percent, which was significantly below pre-crisis levels.

\section{Lessons from the Case Studies}

Government-assisted recapitalizations are designed to bolster banks' capital as a means to increase the supply of credit, and to avoid adding to the supply of liquidated assets, to alleviate downward pressure on the price of risky assets. They do not address the need to recognize loan 
losses, nor do they directly tackle the problem of improving debtor capacity. Recapitalizations, however, may make it easier for banks to recognize losses, and therefore, may facilitate corporate restructuring. Recapitalizations also do no affect incentives for borrowers to improve future behavior as losses are not imposed on corporate borrowers. Whether banks' shareholders stand to lose under a recapitalization program depends on how the government-assistance is structured. Recapitalizations typically do not involve losses for bank creditors.

The main problem with government-assisted recapitalizations of financial institutions is that they can create moral hazard for banks' shareholders, especially if the extent of government recapitalization is small relative to the negative net worth of recipient banks. When assistance is small relative to losses, banks face little incentive to restate their position honestly, to engage in appropriate risk management or capital accumulation as a condition for receiving assistance, or to subject themselves to regulatory monitoring and discipline. And even if banks were willing, there may not exist a credible supervisory authority with sufficient enforcement capacity to ensure that recapitalization leads to a recognition of losses, proper rebuilding of capital, and prudent risk management.

Bank recapitalization (RFC-style assistance to banks) worked well in the U.S. in the 1930s because of appropriate screening and incentives for participants that ensured that the banks worth saving received taxpayer funds, and that they managed their risk and capital structure prudently. Deeply insolvent banks were closed by either the market or by the bank supervisors. Banks receiving aid met specific conditions and were monitored to ensure that they made proper use of their assistance. Preferred stock purchases failed in Japan because of lack of political will to distinguish among banks or to discipline banks when allocating assistance. 
Is it possible, in the current protected environment, for government to find a way to provide a credible combination of financial assistance to banks and conditionality that limits the abuse of that assistance?

One approach to doing so would require the adoption of three mutually reinforcing means of limiting such bank abuse: (i) designing programs of assistance that are selective, and thus able to target financial assistance to banks that are worth preserving, (ii) specifying clear quantifiable rules that limit access to preferred stock assistance, and tie assistance to effective risk management by recipient banks, and (iii) enacting capital regulation that establishes meaningful standards for risk-based capital.

With respect to selectivity, Calomiris (1999) suggests using a common stock issuance matching requirement to encourage the best banks to "self-select" to participate in subsidized preferred stock purchases. That approach would attract capital-impaired but relatively healthy banks with high franchise values, but discourage deeply insolvent banks from applying for government subsidies. Those banks' stockholders would be unable to qualify for subsidized preferred stock purchases because they would be unable to find willing purchasers of new matching common stock offerings.

Despite the theoretical attraction of this approach, not all countries will be capable of implementing it. For selectivity to result in successful bank recapitalization, rules must be enforced rigorously, including bank capital regulations and limitations on dividends. For countries where political influence is strong and regulatory discipline is weak, a preferred stock subsidy based on a common stock matching requirement is unlikely to achieve its desired result. 


\section{Conclusions}

This paper has reviewed seven types of resolution policy, described various cases of their implementation, and compared resolution approaches according to a number of criteria that relate to effectiveness or cost. In theory, the goal of resolution policy is to achieve the necessary rebuilding of banks' and borrowers' balance sheets at the lowest cost, where costs include costs from taxpayers' transfers of wealth and the worsening of incentives in the financial system. Incentives at the margin are crucial to getting the most bang for the least moral hazard distortion. Relatively successful mechanisms share the ability to work with market participants' incentives to achieve their results (i.e, the RFC in the U.S. in contrast to preferred stock assistance in Japan; the Punto Final program in Mexico in contrast to its predecessor, FOBAPROA; sales of banks to foreigners rather than capital injections to domestic banks). When considering incentives, government should be aware that loss sharing between government and private agents can act as a screening device to minimize current costs and distortions for the future, while saving those financial institutions and corporate borrowers that are worth saving and restoring their balance sheets and incentives.

Our second theoretical conclusion is that the strengths and weaknesses of different resolution approaches differ, assuming that those approaches are executed properly. Some approaches target the health of borrowers, others the health of banks. Some approaches (e.g., debt forgiveness via a legal redefinition of debt values) entail lower direct costs to taxpayers than others. Some approaches necessarily have worse incentive consequences for banks or borrowers than others. Thus, policy makers that attach differing weights to the various objectives of resolution policy should choose and design combinations of resolution mechanisms accordingly. 
Our third conclusion is that when choosing a resolution approach, or a set of approaches, policy makers should also take into account the pitfalls they are likely to experience in executing each resolution approach, and that these pitfalls are a predictable consequence of particular country circumstances, and in particular, the legal, regulatory, and political institutions, and the industrial organization structure of the economy.

In particular, we take an important lesson of our case studies to be that the advantages from allowing foreign bank entry are less dependent on a favorable political environment. In this respect foreign bank entry is exceptional. Indeed, as our case studies illustrate, once foreign banks are permitted to operate, they help to make the financial sector more resistant to political influence peddling (see also Kroszner 1998). The case studies illustrate that countries operating with different levels of political and legal/regulatory institutional quality might optimally choose different approaches to resolution policy. Also, the magnitude of a crisis and type of crisis affects the appropriate choices of resolution tools.

For example, in the United States circa 1988, when the political will to cease forbearing and finally deal with the S\&L debacle finally emerged, the government, thrift regulators and supervisors, and the Resolution Trust Corporation moved swiftly and effectively to close or otherwise resolve insolvent institutions, sell foreclosed assets, and force surviving thrifts to recapitalize. The operation of the Swedish AMCs indicates similar success. Underlying those successes were the institutional foundations of mature capitalist economies, including (i) a commitment to the rule of law and the enforcement of creditors' rights in courts, (ii) a longstanding relatively successful tradition in bank supervision and regulation, (iii) relatively liquid markets for the sale of assets, (iv) a political process that is relatively free of corruption, and (v) the fiscal capacity to finance financial sector resolution costs. 
But, as our case studies from emerging markets illustrate, the successful implementation of AMCs in developed economies, like other resolution mechanisms, has not been imitated in emerging market countries, largely because of institutional barriers to success. The problem is that the institutional foundations on which successful AMC liquidation depend - creditors' rights, including the ability to foreclose easily, the absence of favoritism and corruption in the implementation of asset acquisition and resale, and the existence of a bank supervisory and regulatory system that will force banks to honestly recognize losses, manage risk, and recapitalize as necessary - simply do not exist in the vast majority of emerging market economies.

For this reason, emerging market policy makers would benefit from recognizing the inherent limitations of implementing both market-based and government-based resolution policies in emerging markets, and from employing resolution techniques that are less dependent on the favorable preconditions that they do not enjoy. Most obviously, that recognition would lead to less reliance on AMCs, but it would also mitigate the desirability of otherwise highly desirable, but relatively complicated, selective market-based resolution strategies like the RFC and Punto Final, which rely on significant discretionary and oversight authority to be successful.

We have noted, in particular, that self-selection mechanisms that link government preferred stock purchases to privately raised equity (like the RFC), or that link governmentsubsidized debt forgiveness to borrower-bank resolution agreements or to new credit supplied by banks (like Punto Final) may be superior mechanisms for rebuilding bank and borrower balance sheets, in principle. By effectively screening for quality through self-selection, these sorts of assistance programs mitigate moral hazard problems and limit the fiscal costs of bailouts. But we 
have also noted that these mechanisms depend even more than AMCs on favorable institutional preconditions for their success.

We conclude, therefore, that emerging market countries with the weakest institutional conditions may be best served by relying on simple assistance measures that can achieve speedy resolution with less dependence on a high level of political, legal, or economic institutional maturity. The most obvious candidates are across-the-board debt forgiveness via the simultaneous redefinition of the numeraire of debt contracts and bank deposits, or permitting entry by foreign banks. Both approaches have some drawbacks.

Debt forgiveness is less helpful in the long run if the government cannot credibly commit to reserving debt forgiveness as a policy to be used only in the most extreme circumstances, and may not be successful in restarting the credit supply process on a sound footing without an efficient legal and bankruptcy system in credit markets to give incentives to borrowers to continue to service the remainder of outstanding debt, and a supervisory framework that forces banks to take advantage of their improved circumstances by rebuilding their capital positions as need be. For governments in most developing countries, it will be difficult to credibly commit to unrepeated debt forgiveness.

The drawback of foreign bank entry is that it can only restart the arms-length credit supply process if legal institutions protecting creditors' rights are sufficiently developed. Again, this is not the case in most developing countries. Nonetheless, in the imperfect world of emerging market finance, foreign bank entry may often be the best policy option available. 


\section{References}

Anari, Ali, James Kolari, and Joseph R. Mason. 2002. "Bank Asset Liquidation and the Propagation of the Great Depression.” Wharton Financial Institutions Center Working Paper \#02-35, August.

Bagehot, Walter. 1873. Lombard Street: A Description of the Money Market. New York: Scribner, Armstrong.

Barth, James R., and Philip F. Bartholomew. 1992. "The Thrift Industry Crisis: Revealed Weaknesses in the Federal Deposit Insurance System." in: J.R. Barth and R.D. Brumbaugh, Jr. (eds.), The Reform of Federal Deposit Insurance. New York: Harper Business, 36-116.

Berggren, Arne. 1995. "Events Leading to the Need of General Measures in a Bank Crisis: The Swedish Experience." mimeo, August.

Bernanke, Ben S. 1983. "Nonmonetary Effects of the Financial Crisis in the Propagation of the Great Depression." American Economic Review 73(3): 257-276.

Brewer, Elijah, III. 1995. "The Impact of the Current Deposit Insurance System on S\&L Shareholders' Risk/Return Tradeoffs." Journal of Financial Services Research 9: 65-89.

Burns, Arthur F., and Wesley C. Mitchell. 1946. Measuring Business Cycles. New York: National Bureau of Economic Research.

Calomiris, Charles W. 1989. "Deposit Insurance: Lessons from the Record," Federal Reserve Bank of Chicago Economic Perspectives 13: 10-30.

Calomiris, Charles W. 1993a. "Financial Factors and the Great Depression." Journal of Economic Perspectives 7: 61-85.

Calomiris, Charles W. 1993b. "Greenback Resumption and Silver Risk: The Economics and Politics of Monetary Regime Change in the United States, 1862-1900." in M.D. Bordo and F. Capie (eds.), Monetary Regimes in Transition, Cambridge: Cambridge University Press, 86-134.

Calomiris, Charles W. 1998. "Evolution of the Mexican Banking System." Unpublished manuscript.

Calomiris, Charles W. 1999. "Building an Incentive-Compatible Safety Net." Journal of Banking and Finance 23: 1499-1519.

Calomiris, Charles W., and Mark S. Carey. 1994. "Loan Market Competition Between Foreign and Domestic Banks: Some Facts About Loans and Borrowers," Proceedings of the $30^{\text {th }}$ Annual Conference on Bank Structure and Competition, Federal Reserve Bank of Chicago, 331-51.

Calomiris, Charles W., and Gary Gorton. 1991. "The Origins of Banking Panics: Models, Facts, and Bank Regulation," in R.G. Hubbard (ed.), Financial Markets and Financial Crisis. Chicago: University of Chicago Press, 109-173.

Calomiris, Charles W., and Charles M. Kahn. 1991. "The Role of Demandable Debt in Structuring Optimal Banking Arrangements." American Economic Review 81: 497-513.

Calomiris, Charles W., and Joseph R. Mason. 1997. "Contagion and Bank Failures During the Great Depression: The June 1932 Chicago Banking Panic.” American Economic Review 87(5): 863-883.

Calomiris, Charles W., and Joseph R. Mason. 2003a. "How to Restructure Failed Banking Systems: Lessons from the U.S. in the 1930s and Japan in the 1990s." NBER working paper no. 9624. In: Privatization, Corporate Governance and Transition Economies in 
East Asia. Takatoshi Ito and Anne Krueger, eds. Chicago: University of Chicago Press 2003 (forthcoming).

Calomiris, Charles W., and Joseph R. Mason. 2003b. "Fundamentals, Panics, and Bank Distress During the Depression." American Economic Review, forthcoming.

Calomiris, Charles W., and Joseph R. Mason. 2003c. "Consequences of Bank Distress During the Great Depression." American Economic Review 93: 937-947.

Calomiris, Charles W., and Andrew Powell. 2001. "Can Emerging Market Bank Regulators Establish Credible Discipline? The Case of Argentina, 1992-1999," in F. S. Mishkin, ed., Prudential Supervision, Chicago: University of Chicago Press, 147-196.

Calomiris, Charles W., and Berry Wilson. 2003. "Bank Capital and Portfolio Management: The 1930s Capital Crunch and Scramble to Shed Risk." Journal of Business, forthcoming.

Claessens, Stijn, Simeon Djankov, and Daniela Klingebiel. 1999. "Financial Restructuring in East Asia: Halfway There?” World Bank Financial Sector Discussion Paper No. 3.

Claessens, Stijn, Daniela Klingebiel, and Luc Laeven. 2003. Financial Restructuring in Systemic Crises: What Policies to Pursue? In: Michael P. Dooley and Jeffrey A. Frankel (Eds.), Managing Currency Crises in Emerging Markets. The University of Chicago Press.

Cull, Robert. 1998. "Structural Change: Internationalization, Consolidation, and Privatization in Argentina's Banking Sector." Mimeo, World Bank.

Dages, B. Gerard, Linda Goldberg, and Daniel Kinney. 2000. "Foreign and Domestic Bank Participation in Emerging Markets: Lessons from Mexico and Argentina." Federal Reserve Bank of New York Economic Policy Review: 17-36.

Delaney, John A. 1954. "Field Administration in the Reconstruction Finance Corporation." Ph.D. Dissertation, George Washington University.

Demirguc-Kunt, Asli, and Enrica Detragiache. 2000. "Does Deposit Insurance Increase Banking System Stability?" Working Paper, The World Bank.

Demirguc-Kunt, Asli, Ross Levine, and Hong-Ghi Min. 1998. "Opening to Foreign Banks: Issues of Stability, Efficiency, and Growth." in Seongtae Lee (ed.), The Implications of Globalization of World Financial Markets, Seoul: Bank of Korea.

Diamond, Douglas, and Raghuram Rajan. 2001. "Liquidity Risk, Liquidity Creation and Financial Fragility: A Theory of Banking." Journal of Political Economy 109(2): 287327.

Drees, Burkhard, and Ceyla Pazarbasioglu. 1998. "The Nordic Banking Crisis: Pitfalls in Financial Liberalization." Occasional Paper No. 161, International Monetary Fund.

Eichengreen, Barry. 1992. Golden Fetters: The Gold Standard and the Great Depression, 19191939. Oxford: Oxford University Press.

Englund, Peter. 1999. "The Swedish Banking Crisis: Roots and Consequences." Oxford Review of Economic Policy 15(3): 80-97.

Enoch, C., B. Baldwin, O. Frécaut, and A. Kovanen, 2001. "Indonesia: Anatomy of a Banking Crisis. Two Years Living Dangerously, 1997-99," IMF Working Paper No. 01/52, May.

Fisher, Irving. 1933. "The Debt Deflation Theory of Great Depressions." Econometrica 1: 337357.

Friedman, Milton, and Anna J. Schwartz. 1963. A Monetary History of the United States. Princeton: Princeton University Press.

Garber, Peter. 1998. "Derivatives in International Capital Flows." NBER working paper No. 6623. 
Goldberg, Linda, B. Gerard Dages, and Daniel Kinney. 2000. "Foreign and Domestic Participation in Emerging Markets: Lessons from Mexico and Argentina." NBER working paper No. 7714.

Hammond, Bray. 1970. Sovereignty and an Empty Purse: Banks and Politics in the Civil War. Princeton: Princeton University Press.

Honohan, Patrick and Daniela Klingebiel. 2003. "The Fiscal Cost Implications of an Accommodating Approach to Banking Crises." Journal of Banking and Finance 27(8): 1539-1560.

Hovakimian, Armen, Edward J. Kane, and Luc Laeven. 2003. "How Country and Safety-Net Characteristics Affect Bank Risk-Shifting." Journal of Financial Services Research 23: 177-204.

International Monetary Fund, 2000. "Indonesia: Selected Issues," IMF Country Report No.00/132, October.

International Monetary Fund. 2001a. "Mexico: Financial System Stability Assessment." IMF Country Report No. 01/192, October.

International Monetary Fund, 2001b. "Thailand: Selected Issues," IMF Country Report No. 01/147, August.

James, Cyril F. 1938. The Growth of Chicago Banks. New York: Harper \& Bros.

Keynes, John M. 1931. "The Consequences to Banks of the Collapse of Money Values," republished in Essays in Persuasion. New York: W.W. Norton, 1963, 168-180.

Klingebiel, Daniela. 2000. "The Use of Asset Management Companies in the Resolution of Banking Crises. Cross-Country Experience.” World Bank Policy Research Paper 2284.

Kroszner, Randall. 1998. "On the Political Economy of Banking and Financial Regulatory Reform in Emerging Markets." Research in Financial Services 10: 33-51.

Kroszner, Randall. 1999. "Is It Better to Forgive than to Receive? Repudiation of the Gold Indexation Clause in Long-Term Debt During the Great Depression." mimeo, November.

La Porta, Rafael, Florencio Lopes-de-Silanes, Andrei Shleifer, and Robert Vishny. 1998. "Law and Finance." The Journal of Political Economy 106(6): 1113-1155.

La Porta, Rafael, Florencio Lopez-de-Silanes, and Guillermo Zamarripa. 2003. "Related Lending." Quarterly Journal of Economics 118(1): 231-268.

Lindgren, Carl-Johan, T. Baliño, C. Enoch, A. Gulde, M. Quintyn, and L. Teo, 1999. "Financial Sector Crisis and Restructuring: Lessons from Asia," IMF Occasional Paper No. 188.

Macaulay, Frederick. 1938. "Some Theoretical Problems Suggested by the Movements of Interest Rates, Bond Yields, and Stock Prices in the United States Since 1856." New York: National Bureau of Economic Research.

Mackey, Michael W. 1999. Report on the Comprehensive Evaluation of the Operations and Functions of the Fund for the Protection of Bank Savings "FOBAPROA" and Quality of Supervision of the FOBAPROA Program 1995-1998.

Mason, Joseph R. 1996. "The Determinants and Effects of Reconstruction Finance Corporation Assistance to Banks During the Great Depression." Ph.D. Dissertation, University of Illinois.

Mason, Joseph R. 2001. "Do Lender of Last Resort Policies Matter? The Effects of Reconstruction Finance Corporation Assistance to Banks During the Great Depression." Journal of Financial Services Research 20: 77-95.

McQuerry, Elizabeth. 1999. "The Banking Sector Rescue in Mexico," Federal Reserve Bank of Atlanta Economic Review, Third Quarter. 
Merton, Robert. 1977. "An Analytical Derivation of the Cost of Deposit Insurance Loan Guarantees: An Application of Modern Option Pricing Theory." Journal of Banking and Finance 1: 3-11.

Mitchell, Wesley C. 1903. A History of the Greenbacks. Chicago: University of Chicago Press. Mulás, Alberto. 2001. "Corporate Debt Restructuring in a Systemic Financial Crisis: Mexico's Experience, 1996-1998.” in: Claessens S., S. Djankov, and A. Mody (eds.) Resolution of Financial Distress: An International Perspective on the Design of Bankruptcy Laws. WBI Development Studies, pp. 149-166.

Olson, James S. 1972. "The End of Voluntarism: Herbert Hoover and the National Credit Corporation." Annals of Iowa 41: 1104-1113.

Olson, James S. 1977. Herbert Hoover and the Reconstruction Finance Corporation, 1931-1933. Ames, Iowa: Iowa State University Press.

Olson, James S. 1988. Saving Capitalism. Princeton: Princeton University Press.

Packer, Frank. 2000. "The Disposal of Bad Loans in Japan: The Case of the CCPC." in T. Hoshi and H. Patrick (eds.), Crisis and Change in the Japanese Financial System. Kluwer Academic Publishers.

Packer, Frank, and Marc Ryser. 1992. "The Governance of Failure: An Anatomy of Corporate bankruptcy in Japan.” Center on Japanese Economy and Business Working Paper No. 62, Columbia University.

Peek, Joe, and Eric S. Rosengren. 2002. "Corporate Affiliations and the (Mis)Allocation of Credit." University of Kentucky, working paper.

Scott, David, 2002. "A Practical Guide to Managing Systemic Financial Crises," World Bank Policy Research Paper No. 2843.

Sheard, Paul. 1989. "The Main Banking System and Corporate Monitoring and Control in Japan." Journal of Economic Behavior and Organization 11: 399-422.

Temin, Peter. 1989. Lessons from the Great Depression, Cambridge Mass.: MIT Press.

Wicker, Elmus. 1996. The Banking Panics of the Great Depression. Cambridge: Cambridge University Press.

World Bank. 1998. “Argentina: Financial Sector Review.” Report No. 17864-AR, September.

World Bank, 1999. "Republic of Korea: Establishing a New Foundation for Sustained Economic Growth," Poverty Reduction and Economic Management Unit, East Asia and Pacific Region, World Bank.

World Bank. 2000. "Thailand: Social and Structural Review. Beyond the Crisis: Structural Reform for Stable Growth." World Bank Economic Report, January.

World Bank. 2001. Mexico: Report on Proposed Second Bank Restructuring Facility Adjustment Loan." World Bank. 